\title{
Tectonic evolution and high-pressure rock exhumation in the Qiangtang terrane, central Tibet
}

\author{
Z. Zhao ${ }^{1,2}$, P. D. Bons ${ }^{1}$, G. Wang ${ }^{2}$, A. Soesoo ${ }^{3}$, and Y. Liu ${ }^{4}$ \\ ${ }^{1}$ Department of Geosciences, Eberhard Karls University Tübingen, Wilhelmstrasse 56, 72074 Tübingen, Germany \\ ${ }^{2}$ School of Earth Science and Resources, China University of Geosciences, Beijing 100083, China \\ ${ }^{3}$ Institute of Geology, Tallinn University of Technology, Ehitajate tee 5, Tallinn 19086, Estonia \\ ${ }^{4}$ State Key Laboratory for Continental Tectonics and Dynamics, Institute of Geology, CAGS, Beijing 100037, China \\ Correspondence to: Z. Zhao (zhongbao.zhao@ifg.uni-tuebingen.de)
}

Received: 8 January 2015 - Published in Solid Earth Discuss.: 23 January 2015

Revised: 30 March 2015 - Accepted: 8 April 2015 - Published: 30 April 2015

\begin{abstract}
Conflicting interpretations of the $>500 \mathrm{~km}$ long, east-west-trending Qiangtang metamorphic belt have led to very different and contradicting models for the PermoTriassic tectonic evolution of central Tibet. We define two metamorphic events, one that only affected pre-Ordovician basement rocks and one subduction-related Triassic highpressure metamorphism event. Detailed mapping and structural analysis allowed us to define three main units that were juxtaposed due to collision of the north and south Qiangtang terranes after closure of the Ordovician-Triassic ocean that separated them. The base is formed by the Precambrian-Carboniferous basement, followed by nonmetamorphic ophiolitic mélange containing mafic rocks that range in age from the Ordovician to Middle Triassic. The top of the sequence is formed by strongly deformed sedimentary mélange that contains up to $>10 \mathrm{~km}$ size rafts of both unmetamorphosed Permian sediments and highpressure blueschists. We propose that the high-pressure rocks were exhumed from underneath the south Qiangtang terrane in an extensional setting caused by the pull of the northward subducting slab of the Shuanghu-Tethys. Highpressure rocks, sedimentary mélange and margin sediments were thrust on top of the ophiolitic mélange that was scraped off the subducting plate. Both units were subsequently thrust on top of the south Qiantang terrane continental basement. Onset of Late Triassic sedimentation marked the end of the amalgamation of both Qiangtang terranes and the beginning of spreading between Qiantang and north Lhasa to the south, leading to the deposition of thick flysch deposits in the Jurassic.
\end{abstract}

\section{Introduction}

The Tibetan plateau is an amalgamation of terranes that were accreted to the southern margin of Eurasia during Phanerozoic times (Yin and Harrison, 2000). From north to south, these terranes are the Qilian Shan, Qaidam, Songpan-Ganzi flysch complex, Qiangtang and Lhasa terranes (Fig. 1a). Terrane boundaries are defined by widely scattered belts of ophiolitic fragments and mélanges with high-pressure rocks (Zhu et al., 2012). These represent the opening and closure of several oceans. However, which ocean subducted where, when and in which direction is still subject of ongoing controversy. For example, Triassic subduction mélange and high-pressure rocks that are exposed in the Qiangtang metamorphic belt in central Tibet are interpreted in radically different ways (Kapp et al., 2003b; Li et al., 2006; Zhai et al., 2011a; Liang et al., 2012; Zhao et al., 2014).

$\mathrm{Li}$ et al. (1987) interpreted the blueschists and subduction mélange as the remnants of a Late Triassic suture zone. They proposed that the Qiangtang terrane was separated into a northern and a southern terrane by the Paleo-Tethys Ocean. As a result of northward subduction of this PaleoTethys underneath the north Qiangtang terrane (NQT), highpressure rocks and subduction mélange were thrusted southward onto the south Qiangtang terrane (SQT) (Zhang et al., 2006b; Zhai et al., 2011b; Zhao et al., 2014). The inferred suture between the two terranes is called the Longmu CoShuang Hu suture (short "Shuanghu" suture). The alternative to this "overthrust" model is the "underthrust" model of Kapp et al. (2000, 2003b) and Pullen and Kapp (2014), in 


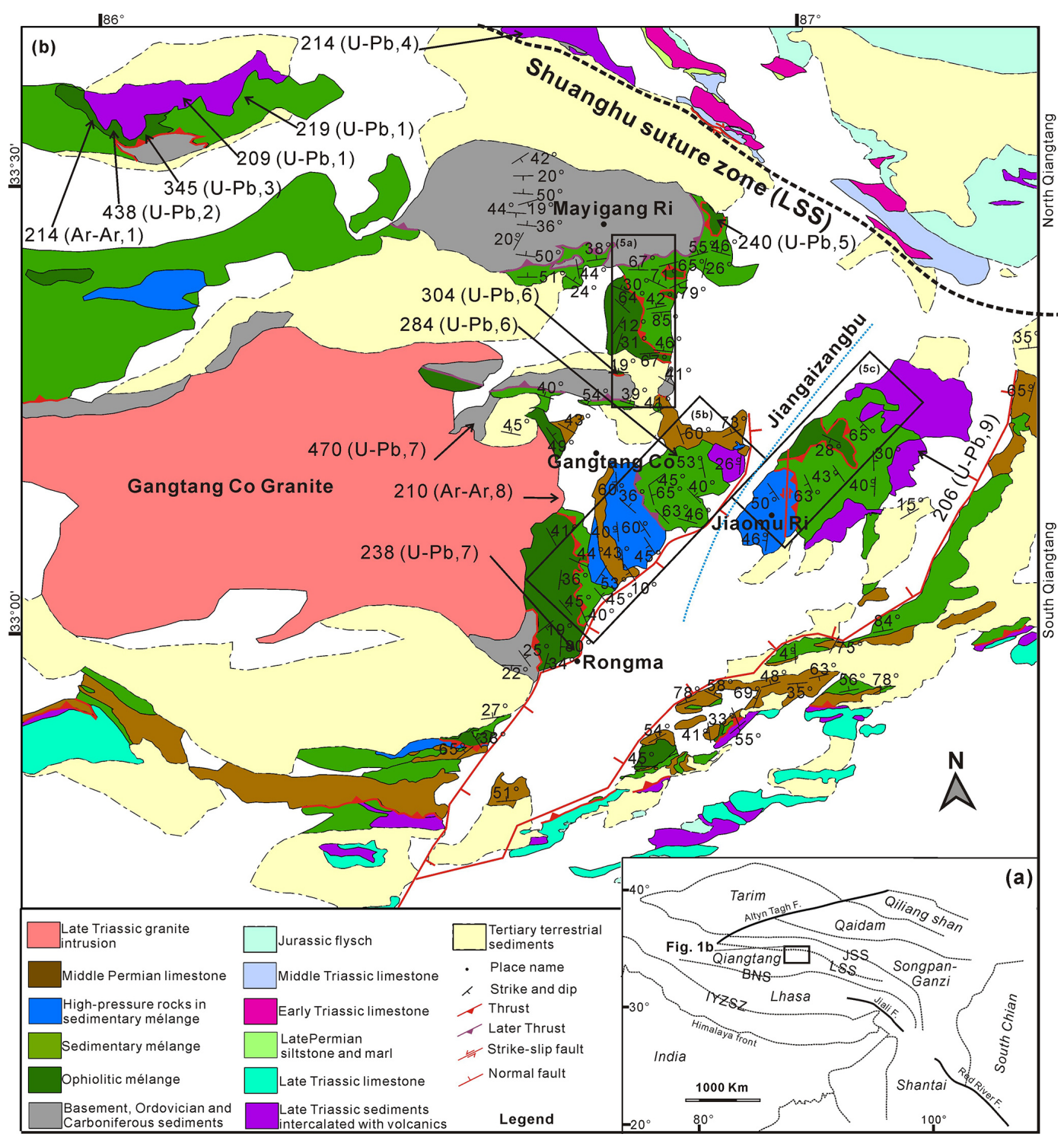

Figure 1. (a) Structural sketch of Tibet. From north to south, the sutures are Jinsha suture zone (JSS); Longmu Co-Shuanghu suture zone (LSS); Bangong-Nujiang suture zone (BNS); and Indus-Yarlung suture zone (IYSZ). (b) Geological map of the study area (rectangle in (a)) around Rongma on the northern margin of the south Qiangtang terrane. The LSS zone separates the south Qiangtang from the north Qiangtang terrane in the northeast of the area. Strikes and dips are the properties of main tectonic foliation in strongly deformed rocks, while bedding is the property of less deformed rocks. Rectangles show the locations of structural reconstructions in Fig. 5. Numbers in parentheses refer to the following references: (1) Li et al. (2007); (2) Zhai et al. (2010); (3) Zhai et al. (2013b); (4) Wang et al. (2008a); (5) unpublished data; (6) Zhai et al. (2009); (7) Zhao et al. (2014); (8) Kapp et al. (2003b); (9) Zhu (2005).

which the Paleo-Tethys separated a single Qiangtang terrane in the south and the Songpan-Ganzi flysch complex in the north. The Paleo-Tethys subducted to the south underneath the Qiangtang terrane along the Jinsha suture (JSS). Highpressure rocks and mélange were subsequently exhumed by core-complex-like normal faulting and doming in the middle of the Qiangtang terrane. To avoid confusion of the names of the various oceans, we use the term "Shuanghu-Tethys" for the ocean that is proposed to have separated the SQT and NQT and subducted at the Shuanghu suture.
The two different models thus predict totally different tectonic histories of central Tibet and, therefore, the initial boundary conditions for Cenozoic growth of the Tibetan plateau. Here we present the results of detailed mapping and structural reconstruction of the Rongma area in the centre of the Qiangtang metamorphic belt. These results support the overthrust model and thus indicate that the north and south of the Qiangtang terrane were once separated by an ocean that closed in the Late Triassic. 


\section{Regional setting}

The Qiangtang terrane is located in the centre of the Tibetan plateau (Fig. 1a). It extends for more than $1200 \mathrm{~km}$ from east to west and reaches a maximum width of $\sim 500 \mathrm{~km}$. Southeast of the Tibetan plateau it connects with the Sibumasu terrane (Metcalfe, 2009). The Songpan-Ganzi flysch complex lies to the north of it, with the Jinsha Suture Zone (JSS) in-between (Yin and Harrison, 2000). This suture zone represents the Paleo-Tethys (or a branch of it) between Eurasia and the Qiangtang terrane that was consumed by southward subduction beneath the Qiangtang terrane in Late Triassic to Early Jurassic times (Dewey et al., 1988; Nie et al., 1994; Yin and Nie, 1996; Kapp et al., 2003b). The BangongNujiang suture zone (BNS) separates the Qiangtang terrane from the Lhasa terrane to the south. It is characterized by an $>1200 \mathrm{~km}$ long EW-trending belt of widely scattered ophiolitic fragments that are associated with a thick sequence of mainly Jurassic flysch, mélange and volcanic rocks (Wang et al., 1983). The belt exhibits an anomalously large acrossstrike width, especially in far western Tibet between Rutog and Shiquanhe and northwest of Lhasa between Xainza and Amdo (Kapp et al., 2003a).

Some regard the Qiangtang terrane as a single terrane (Kapp et al., 2003b; Pullen et al., 2011) that, together with the Sibumasu terrane, separated from Gondwana in Paleozoic times (Metcalfe, 2009). Others divided the terrane into a north Qiangtang and a south Qiangtang terrane ( $\mathrm{Li}$ et al., 2009; Liu et al., 2011). In this model, the two terranes were separated by the Shuanghu suture that closed in Late Triassic times by northward subduction of ocean underneath the NQT. This north-south division will be used throughout this paper. It should be noted that the SQT and NQT are equivalent to the east and west Qiangtang terranes of Zhu et al. (2012) respectively.

In the SQT, the autochthonous units consist of low metamorphic-grade pre-Ordovician basement, unconformably overlain by Middle Ordovician siltstone and Carboniferous flysch and sandstone, including glaciomarine deposits, all with Gondwana affinity (Zhao et al., 2014). Only Late Devonian limestones and Early Carboniferous limestone intercalated with siltstone are exposed on the southern margin of the NQT. Permian sediments are different in the NQT and SQT. In the SQT, only Middle Permian limestones are exposed, characterized by cold-water fauna (Li et al., 1995; Zhang and Tang, 2009). In the NQT, only Late Permian sedimentary rocks are found, comprising sandstone, mudstone and limestone with abundant warmwater fusulinid and coral fossils of Cathaysian affinity ( $\mathrm{Li}$ et al., 1995; Zhang and Tang, 2009). Lower to Middle Triassic sediments are only found on the southern margin of the NQT (Fig. 1b). These are bathyal sediments including fossiliferous limestone, massive limestone, oolitic limestone and minor intercalated sandstone and siltstone layers.
Late Triassic terrestrial sediments, limestones and volcanics are the first post-collisional deposits in both the SQT and NQT. Magmatic arc volcanics dominate on the southern margin of the NQT (Zhai and Li, 2007; Zhai et al., 2013a), whereas the occurrence of limestone increases towards the south. During the Jurassic, marine sediments were deposed on both the SQT and NQT, while Cretaceous limestones are only found on the SQT (Kapp et al., 2005). Tertiary, and possibly also late Cretaceous, conglomerates unconformably overlie all above rocks in intramontane, fault-bounded basins (Kapp et al., 2005).

High-pressure rocks, including blueschists and eclogites, as well as subduction mélange with ophiolitic fragments are found scattered over an $>500 \mathrm{~km}$ long, EW-striking belt in the middle of the Qiangtang terrane: the central Qiangtang metamorphic belt (Kapp et al., 2003b; Zhang et al., 2006a; Liu et al., 2011). Ar-Ar analyses on synkinematic phengite, zircon $\mathrm{U}-\mathrm{Pb}$ and $\mathrm{Lu}-\mathrm{Hf}$ isotopic ages from high-pressure units yielded ages from 244 to $214 \mathrm{Ma}$ (Pullen et al., 2008; Zhai et al., 2011b), which is interpreted to provide an estimate for the age of suture zone closing (Li et al., 2009) as well as exhumation of the high-pressure rocks. These ages coincide with those of granitoids in the Qiangtang terrane, which range in age from 234 to $177 \mathrm{Ma}$ (Zhang et al., 2011). Only one Late Triassic granite, the $\sim 210 \pm 4$ Ma Gangtang Co granite (Kapp et al., 2003b) is found in the SQT within the study area. This large, undeformed granite intruded both mélange and basement rocks (Kapp et al., 2003b; Zhao et al., 2014). This granite thus marks the end of collisional activity and is approximately coeval with volcanic deposits in the NQT and the SQT.

Based on the brief overview above, the rocks in the Qiangtang terrane can be divided into three groups. The first consists of autochthonous continental crustal rocks older than the Late Triassic ocean closure, including pre-Ordovician basement rocks and overlying Ordovician to Triassic units. Units deposited after closure, including the Gangtang Co granite, form the second autochthonous series. These range from Late Triassic sediments and volcanics to recent terrestrial deposits. The third group is formed by the mélange and high-pressure rocks and also includes blocks and rafts of the older autochthonous series rocks. The two conflicting models make testable predictions on stratigraphy, metamorphic grade and structural relationships between the different rock units in the study area. These are briefly discussed here. This is followed by a more detailed overview of the stratigraphy in the critical period from the Permian to the Triassic and a structural geological analysis. The observations are then compared with the predictions of the different models.

\subsection{Cold- vs. warm-water fauna}

In the underthrust model, the Qiangtang terrane formed one single block that drifted northwards from the Gondwana margin. Permian to Middle Triassic sediments are expected to 


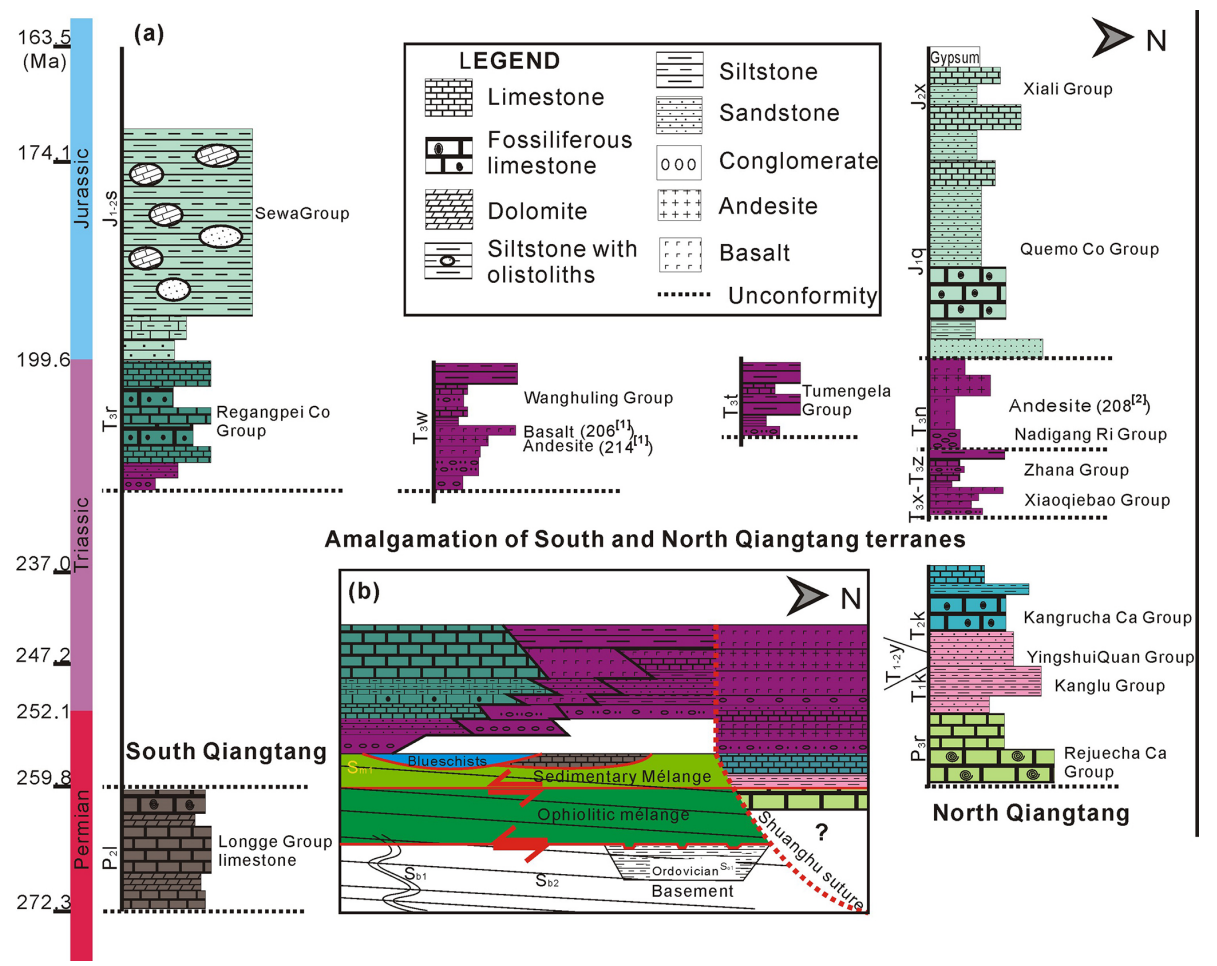

Figure 2. (a) Permian to Jurassic lithostratigraphic columns for the Qiangtang area, from south (left) to north (right); (b) structural and stratigraphic relationships. Basement, ophiolitic mélange and sedimentary mélange with blueschists and Permian sediments form a stack of thrust-bounded sheets. These are unconformably overlain by Late Triassic sediments and volcanics. Sources: (1) Li et al. (2007) and (2) Wang et al. (2008a).

reflect this northward drift by showing a trend from coldto warm-water faunas. Contemporaneous sediments on the NQT and SQT should not show a significant difference in paleolatitude (Pullen and Kapp, 2014). In the overthrust model, the NQT and SQT were separated by an ocean of unknown width. Contemporaneous Permo-Triassic sediments would then be deposited on terranes with potentially significantly different latitude, and cold-water fauna is to be expected in the SQT but not in the NQT (e.g. Li et al., 1995).

\subsection{Metamorphic grade}

In the underthrust model, the mélange is formed between the Qiangtang terrane continental crust and the subducting oceanic plate, which is thought to subduct southward at a shallow angle. This implies that all mélange rocks were once buried below the Qiangtang continental crust, down to a depth of at least $35 \mathrm{~km}$ (Kapp et al., 2003b). In the overthrust model, the mélange, including high-pressure rocks, derives from the Shuanghu suture in the north of the study area. This mélange may include high-pressure rocks but not necessarily exclusively, such as in the case of the Franciscan complex (e.g. Agard et al., 2009). The distribution of metamorphic grade in the allochthonous units is thus an important criterion to distinguish between the two models.

\subsection{Structural position of the mélange}

In the underthrust model, the mélange is exhumed by normal faulting that produced metamorphic core-complex-like domes south of the JSS suture zone. This occurred due to rollback of the subducting slab (Kapp et al., 2000, 2003b; Pullen et al., 2011) or later during Jurassic extension (Fu et al., 2010a). Continental crust should thus lie structurally above the mélange, separated by normal faults. The opposite is to be expected in the overthrust model, which envisages the mélange to be thrust over the SQT. Mélange should then structurally overlie autochthonous crustal rocks, separated by thrusts (Zhao et al., 2014).

\section{The basic stratigraphic and lithological frame in the Qiangtang terrane}

Here we review the Permian to Jurassic stratigraphy of the study area (Fig. 2a), including lithofacies, paleontology and paleogeography, with particular attention to the Late Triassic unconformity. Stratigraphic age assignments were made by correlating lithostratigraphy with biostratigraphic sections within or near the study area. 


\subsection{Pre-collision stratigraphy and lithologies}

Pre-Ordovician basement rocks crop out in the SQT in the Rongma area around the Gangtang Co granite and as a thrust sheet at Mount Mayigang Ri. These rocks are dominantly quartzite and phyllite, experienced greenschist-facies metamorphism and were deformed twice (Zhao et al., 2014). Detrital zircons show that the basement was pre-Ordovician in age and has a Gondwana affinity (Dong et al., 2011). It is unconformably overlain by slates of the Tashishan formation, dated as Middle to Late Ordovician with SinocerasMichelinoceras fossils ( $\mathrm{Li}$ et al., 2004; Zhao et al., 2014). Within the area, Ordovician rocks are only found in two small areas near Rongma Village. The Devonian is only represented in the NQT; in the NQT, Carboniferous limestones are found just northeast of the study area $(\mathrm{Li}, 2006)$. Carboniferous sandstones with cephalopod fossils also unconformably overlie pre-Ordovician basement rocks west of Rongma. Fossiliferous Carboniferous siltstones in the NQT were dated as Late Carboniferous (Wu et al., 2009). Ordovician to Carboniferous sediments are not metamorphosed and only one deformation phase can be recognised by folding, boudinage and cleavage development (Zhao et al., 2014). The first deformation phase observed in the basement is thus preOrdovician, whereas the second must be post-Carboniferous.

Only the Middle Permian Longge Group $\left(\mathrm{P}_{2} \mathrm{l}\right)$ is found in the SQT. This unit comprises massive, poorly bedded reef or platform limestones including micritic bioclastic limestone, sparry oolitic limestone, dolomicrite, and brecciated dolomite. Fossils are abundant, including stromatoporoids, crinoids, brachiopods, gastropods, corals, benthic foraminifera and fusuline, constraining the age to the Middle Permian. This fusuline fauna is characterised by the presence of the distinctive bi-temperate fossils (Zhang et al., 2014). These strata occur as large fault-bounded rafts within the mélange, with a maximum thickness of $\sim 5000 \mathrm{~m}$. Early to Middle Permian strata are absent in the NQT, where only the Upper Permian Rejuechaca Group $\left(\mathrm{P}_{3} \mathrm{r}\right)$ occurs. It consists of grey to light-grey massive bioclastic limestone and dark-green layered micritic limestone with brachiopods and gastropods. These platform limestones reach $>500 \mathrm{~m}$ in thickness and contain marine faunas of typically Cathaysian provenance (Wu and Lang, 1990; Chen et al., 2009; Zhang et al., 2012b).

Late Permian to Middle Triassic strata are missing in the SQT. However, in the NQT, the Lower Triassic Kanglu Group $\left(\mathrm{T}_{1} \mathrm{k}\right)$ conformably overlies the $\mathrm{P}_{3}$ r. Its thickness can reach $\sim 950 \mathrm{~m}$. This unit consists mainly of cyclically alternating purple, yellow or grey fine-grained sandstones, siltstones and marls. The Lower Triassic age is confirmed by the presence of Claraia fossils. The overlying $>1500 \mathrm{~m}$ thick Yingshuiquan Group $\left(\mathrm{T}_{1-2} \mathrm{y}\right)$ consists of light-grey, massive oolitic limestone intercalated with thinly layered quartz and feldspathic sandstone. The limestones are sandy and contain abundant bivalves and brachiopods. The Lower Triassic se- quence is topped by the Kangnan Group $\left(\mathrm{T}_{2} \mathrm{k}\right)(<310 \mathrm{~m})$, which consists of grey-green, fine-grained marls at the base and a bivalve-rich limestone at the top.

\subsection{Syn- to post-collision stratigraphy and lithologies}

The terrane-wide, Late Triassic unconformity marks the end of subduction activity (Zhai et al., 2011a) and the beginning of a new cycle of sedimentation that continued through most of the Mesozoic.

In the NQT, the base of the Late Triassic sequence is formed by $\mathrm{T}_{3} \mathrm{x}$ and $\mathrm{T}_{3} \mathrm{z}$. Polymictic conglomerates, pebbly siltstone and mudstone are found at the base of the Xiaoqiebao Group $\left(\mathrm{T}_{3} \mathrm{x}\right)$. Overlying the basal conglomerate are pillow basalt, basaltic lavas, andesite, rhyolite, tuffites, intraformational breccias and mass flow deposits. These, in turn, are overlain by several tens of metres of coral-bearing limestones and plant-debris-bearing sandstone with some conglomerate. The upper unit is the Zhana Group $\left(\mathrm{T}_{3} \mathrm{z}\right)$ that mainly consists of fine-grained lithic sandstone, tuffaceous sandstone and siltstone (Zhang et al., 2005). The total thickness of these units is more than $2000 \mathrm{~m}$. The Late Triassic Nadigang Ri Group $\left(\mathrm{T}_{3} \mathrm{n}\right)$ in the NQT starts with a set of fluvial conglomerates (Zhu et al., 2013), followed by mainly basaltic volcanic breccia, basalt and layered quartz andesite. Minor terrestrial intervals occur in the predominantly volcanic succession. A rhyolite in this sequence was dated at $208 \mathrm{Ma}$ (Wang et al., 2007). The total thickness of the Nadigang Ri Group is about $800 \mathrm{~m}$.

Sediments of the Late Triassic Tumengela Group $\left(\mathrm{T}_{3} \mathrm{t}\right)$, Jiaomuchaca Group $\left(\mathrm{T}_{3} \mathrm{j}\right)$ and Wanghuling Group $\left(\mathrm{T}_{3} \mathrm{w}\right)$ are found in the middle of the study area, unconformably overlying the mélange. The Tumengela Group is characterized by thick-bedded, coarse to pebbly lithic sandstone and finegrained feldspar-quartz sandstone at base. The middle unit is occupied by a dark-grey, rhythmic sequence of layered carbonaceous shale, silty shale or greyish-yellow calcareous silt. The uppermost part is composed of grey micrite and dark-grey calcareous mudstone (Zhu et al., 2013). The lower part of the $T_{3} j$ consists of conglomerates and platform-facies limestone, while the upper part is formed by reefal limestone with corals, brachiopods, sponges and crinoids (Zhu et al., 2013). Components of the conglomerate include poorly sorted volcanic debris, limestone and chert. The Wanghuling Group commences with a conglomerate with highly variable clasts that include limestone, basalt, sandstone and highpressure rocks. Upwards, the conglomerate grades into sandstone intercalated with siltstone, followed by $\sim 300 \mathrm{~m}$ of tuffaceous sand- and siltstone, rhyolite and limestone intercalations. One rhyolite layer was dated as $214 \pm 4 \mathrm{Ma}$ and actinolite from the underlying units gave an Ar-Ar age of $219.7 \pm 6.5 \mathrm{Ma}$ (Li et al., 2007; Wang et al., 2008a).

On the SQT, Late Triassic sedimentation commenced with conglomerates to sandstones ( $\mathrm{Li}$ and Wen, 2007) unconformably overlying Permian sediments, as well as mélange. 
In the south of the area, the basal clastic sediments are overlain by medium- to thick-bedded clastic sediments and carbonates of the Riganpei Co Group ( $\mathrm{T}_{3} \mathrm{r}$ ) (> $3000 \mathrm{~m}$ ). This fossiliferous group mostly consists of grey micritic limestone and oolitic limestone, intercalated with breccia, calcarenite and shell-clastic limestone, deposited in a marginal sea or carbonate platform (Zhu et al., 2013).

From south to north the Late Triassic shows a transition from shallow marine, carbonate-dominated sediments towards terrestrial fluvial sediments and an increasing amount of bimodal volcanic deposits that dominate the sequence in the NQT (Fig. 2b). Onset of sedimentation progresses from $\sim 220 \mathrm{Ma}$ in the south to $\sim 206 \mathrm{Ma}$ in the north.

\subsection{Post-collision stratigraphy and lithologies}

The Early Jurassic Quemo Co Group ( $\mathrm{J}_{1} \mathrm{q}, \sim 1700 \mathrm{~m}$ thick) unconformably overlies the $\mathrm{T}_{3} \mathrm{n}$ on the NQT. The base of this unit is characterized by coarse clastic rocks deposited in a river-delta environment. This unit grade upwards into several cycles of mud limestone, oolitic limestone, mudstone, argillaceous siltstone and sandstone, representing an overall transgression (Fu et al., 2010b). This is followed by the Middle Jurassic Xiali Group $\left(\mathrm{J}_{2} \mathrm{x}\right)$ that shows a regressive sequence throughout the north Qiangtang basin. The lower part of this unit is composed of mudstone interbedded with sparry oolitic limestone, while the upper part consists of mudstone, micritic limestone and gypsum intercalations (Zhang et al., 2006c).

In the southern part of the area, < $1000 \mathrm{~m}$ thick Jurassic strata of the Sewa Group $\left(\mathrm{J}_{1-2} \mathrm{~s}\right)$ conformably overlie the Triassic $\left(\mathrm{T}_{3} \mathrm{r}\right)$. The group consists of dark shales, siltstones, fine- to medium-grained sandstones with olistoliths, limestone lenses and quartzite. The whole sequence of sandy foreshore or shore facies sediments is possibly related to the earliest stages of basin subsidence in the southern Qiangtang realm during Early Jurassic extension (Duan et al., 2009; Schneider et al., 2003) and Meso-Tethys formation (Baxter et al., 2009). Tertiary (possible even Late Cretaceous) to recent terrestrial sediments, mostly conglomerates, cover the area in scattered, usually fault-bounded basins (Kapp et al., 2005).

\subsection{Lithologies and metamorphism of the mélange in the Qiangtang terrane}

The subduction mélange, only found on the SQT, is divided into three lithologies: (1) ophiolitic mélange (Zhai et al., 2007, 2010), (2) sedimentary mélange consisting of deepwater clastic sediments together with blocks and rafts of high-pressure rocks and (3) Permian limestones (Zhang et al., 2012a; Fig. 1b).

The ophiolitic mélange consists of gabbro, diabase and basalt blocks and lenses, intercalated with deep-water siltstone, with minor chert, mudstone, sandstone and limestone.
The mafic rocks have ocean-island or MORB affinities (Zhai et al., 2004; 2007) and range in age from the Ordovician to Triassic. Ordovician to Carboniferous gabbro ages were reported from rocks in the NW of the study area (Fig. 1b), which were interpreted as Paleozoic ophiolitic segments (Zhai et al., 2009, 2010, 2013b). Permian ophiolitic mélange was first documented by Zhai et al. (2007) in the Jiaomu $\mathrm{Ri}$ area. Northwest of Rongma village, mélange of gabbro blocks, pillow basalt and minor ultramafic blocks embedded in siltstone have Permian and Triassic ages (Li et al., 2009; Zhang et al., 2012a). Most of these mafic rocks preserved their original structures such as amygdules in basalt (Fig. 3a). In a thin section, the gabbros show no signs of strong deformation or of metamorphism (Fig. 3b). That means that the ophiolitic mélange was never buried to significant depths.

The sedimentary mélange is mainly found south of Mayigang $\mathrm{Ri}$, north and east of Jiaomu Ri and in an east-west- to southwest-northeast-trending belt in the southern part of the study area (Fig. 1b). Its composition is highly variable and includes sandstone, siltstone, mudstone, chert, thinly bedded limestone and minor mafic blocks. Competent lithologies are embedded as lenses in a strongly foliated matrix (Fig. 3c). Various sedimentary structures are preserved, such as Bouma sequences, graded bedding, load casts (Fig. 3d) and flute marks. Sections of the stratigraphy are preserved but disturbed by folds and faults (Fig. 3e). The sediments are not metamorphosed, as can be seen from a lack of recrystallisation in a fine-grained siltstone (Fig. 3f). Fossils show that occasional limestone blocks are of Permian age (Zhang et al., 2012a). Preservation of fossils and primary sedimentary microstructures show that the sedimentary mélange was not metamorphosed. However, the Permian limestones in contact with blueschists NE of Rongma trend towards strongly deformed marbles at that contact. The marbles contain assemblages of calcite + tremolitic amphibole \pm epidote \pm garnet \pm quartz, which indicates elevated temperatures (up to $\sim 500^{\circ} \mathrm{C}$ ) but relatively low pressure (Bucher and Frey, 2002). Microstructures indicate strong ductile deformation of the calcite (twinning, dynamic recrystallisation) after at least growth of tremolitic amphibole (Fig. 4a). The garnet, however, appears to have grown posttectonically, implying a syn- to post-tectonic thermal event (Fig. 4b).

High-pressure rocks are found in association with the clastic sediments and Permian limestones of the sedimentary mélange. Main outcrops of high-pressure rocks are located in Jiaomu Ri and south of Gangtang Co (Fig. 1b). They consist of phengite-quartz schists, blueschists and eclogites (Kapp et al., 2003b; Liu et al., 2011; Zhai et al., 2011b; Zhang et al., 2006a). Peak metamorphic age is $\sim 244 \mathrm{Ma}$ and exhumation occurred around 220-214 Ma (Zhai et al., 2011b; Pullen et al., 2011). Maximum temperature and pressure ranges are $410-460^{\circ} \mathrm{C}$ and $2.0-2.5 \mathrm{GPa}$. All authors agree that the exhumation was related to subduction, although the mechanism and plate tectonic setting remains under debate 


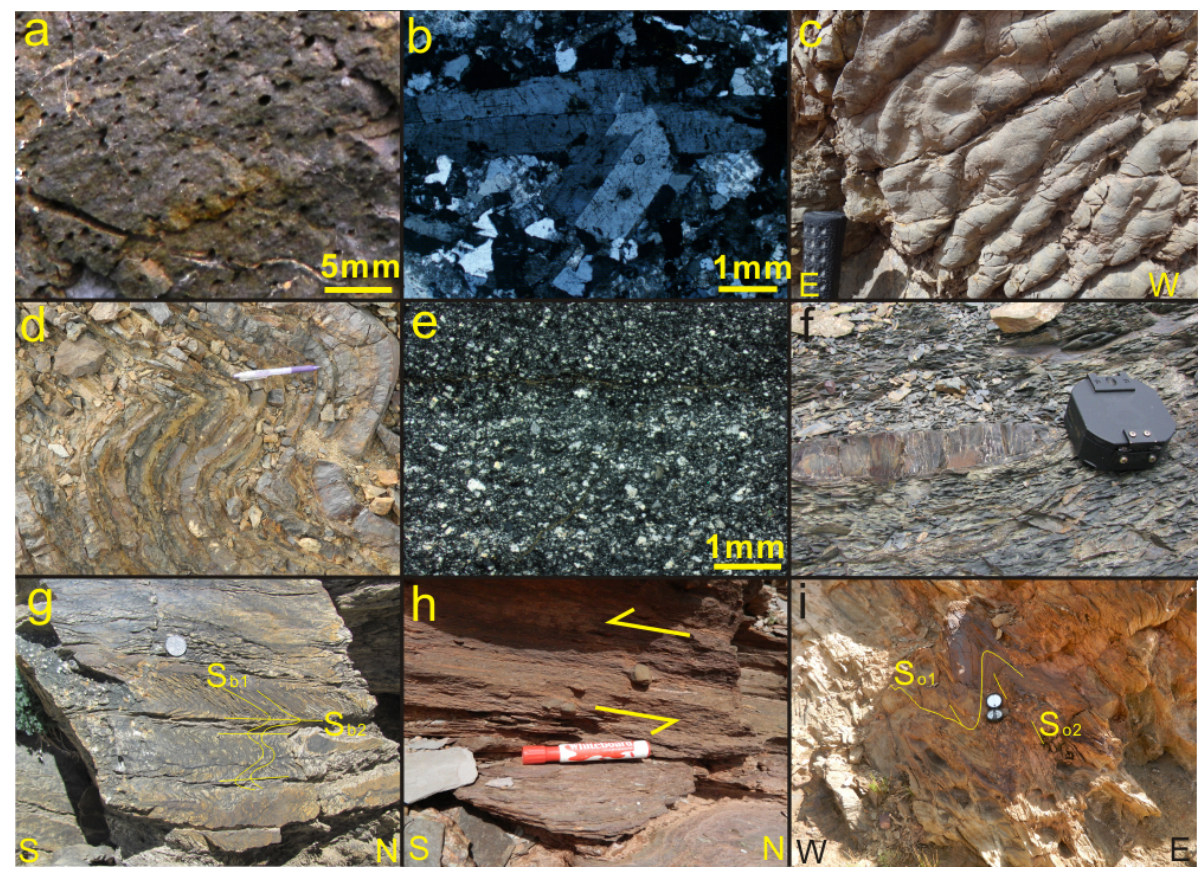

Figure 3. Field photographs and micrographs showing metamorphism and deformation in the different units: (a) amygdules in basalt from the ophiolitic mélange, west of Rongma; (b) thin sections of gabbro, west of Rongma; (c) load cast in mudstone from the southern part of the sedimentary mélange; (d) folded chert from the sedimentary mélange west of Jiangaizangbu River; (e) thin sections of siltstone, west of Rongma, which show that the ophiolitic and sedimentary mélanges did not experience any significant metamorphism; (f) typical main foliation in the sedimentary mélange wrapping around competent blocks, here sandstone; (g) outcrop view of basement deformation: $\mathrm{S}_{\mathrm{b} 1}$ is folded, during which a second, crenulation cleavage $S_{\mathrm{b} 2}$ developed. (h) Pressure shadow around pebbles in the Ordovician siltstone indicate top-to-south shearing. (i) Near the thrust where ophiolitic mélange is thrusted over Ordovician sediments (Fig. 6b), their deformation is more intense, with the local development of an axial planar $\mathrm{S}_{\mathrm{o} 2}$.

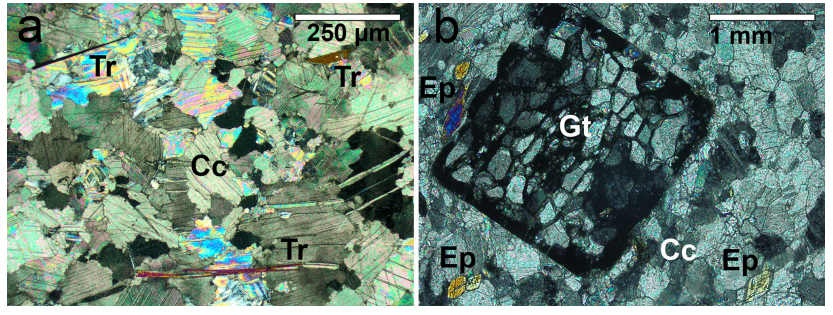

Figure 4. Micrographs (crossed polars) of marbles at the contact between Permian limestone and blueschist, northeast of Rongma; (a) deformed and dynamically recrystallised calcite (Cc) with aligned needles of tremolitic amphibole (Tr); (b) calcite marble with epidote (Ep) and post-tectonic poikiloblastic garnet (Gt).

(Kapp et al., 2003b; Zhang et al., 2006b; Li et al., 2009; Pullen and Kapp, 2014).

At this stage it is useful to compare the stratigraphy described here with that of the detailed map of the Rongma and Jiaomu Ri area of Kapp et al. (2003). These authors define two types of mélange: blueschist and greenschistfacies mélange. The blueschist, which is readily identified in the field and on satellite images, corresponds to the high-pressure rocks described above. According to Kapp et al. (2003), greenschist mélange only occurs west of the Jiangaizangbu valley in areas that we classified as ophiolitic or sedimentary mélange. Large areas that we mapped as mélange, because of the chaotic nature and strong deformation of the rocks, were assigned to an autochthonous Carboniferous (C1-2) to Permian (P1-4) series that overlies the mélange in the interpretation of Kapp et al. (2003). The Carboniferous sandstone, siltstone phyllite and slate (C1) west of Rongma are equivalent to the pre-Ordovician basement and overlying Ordovician and Carboniferous metasediments (Zhao et al., 2014). C1 northeast of Rongma is part of the sedimentary mélange. Fossil evidences show that the $\mathrm{C} 2$ sandy limestone interbedded with siliciclastics actually belongs to the Middle Permian Longge Group $\left(\mathrm{P}_{2} \mathrm{l}\right.$; Zhang et al., 2012a, 2014).

The Permian sequence of Kapp et al. (2003b) begins with turbiditic fine-grained volcaniclastic greywacke, sandstone, siltstone, and slate (P1) and thinly bedded darkgrey limestone (P2), both of which are part of the sedimentary mélange in our interpretation. Part of the basalts, as well as volcano-sedimentary sandstones to conglomerate/breccia (P3), corresponds to the Late Triassic Tumengela Group $\left(\mathrm{T}_{3} \mathrm{t}\right)$ and Wanghuling Group $\left(\mathrm{T}_{3} \mathrm{w}\right)$, the latter dated at $214 \pm 4$ (SHRIMP) to $206 \pm 4$ (Ar-Ar) Ma on rhy- 
olite and basalt of the Wanghuling Group (Zhu et al., 2005; $\mathrm{Li}$ et al., 2007). Other outcrops of $\mathrm{P} 3$ we assigned to either ophiolitic mélange (dominated by mafic rocks) or the sedimentary mélange (dominated by sediments and breccias). The limestone and subordinate sandstone (P4) corresponds to the sediments of the top of the Wanghuling Group in areas where $\mathrm{P} 3$ corresponds to its base. In the remainder of the area northeast of Jiaomu Ri, P3 is mapped as sedimentary mélange.

As pointed out by Zhang et al. (2012b), the differences in stratigraphic and lithological classification clearly have major consequences for the inferred tectonic history of the Qiangtang area. In the map of Kapp et al. (2003b) the area of mélange is less than half that shown in Fig. 1. Furthermore, all mélange is at least greenschist facies, derived from depths of $\sim 35 \mathrm{~km}$. Greenschist-facies rocks can indeed be found in the ophiolitic and sedimentary mélange, but these occur together with non-metamorphic rocks. The whole mélange unit is therefore non-metamorphic, but includes metamorphic rocks from various origins, such as the Qiangtang basement (Zhao et al., 2014).

\subsection{Igneous activity in the Qiangtang terrane}

Apart from the ophiolites, the Qiangtang area records Carboniferous to Jurassic igneous activity. EW-striking diabase dykes intrude basement rocks and were dated at $284 \pm 3$ and $302 \pm 4$ Ma by Zhai et al. (2009). Mostly felsic magmatic activity is dated between about 275 and $248 \mathrm{Ma}$ in the NQT east of the study area and interpreted as related to northward subduction underneath the NQT (Yang et al., 2011; Zhang et al., 2013). This is followed by bimodal activity that continued into the Jurassic (Zhang et al., 2011). Triassic (236-219 Ma) adakites and magnesian andesites from the Tuotuohe area, central NQT, are interpreted as subduction related but indicate that the mantle source was metasomatised by slab melting (Wang et al., 2008b). Some basalts show continental arc affinities, the source most likely being a mixture of MORB- and within-plate basaltic source. This suggests the lithospheric mantle may be slightly to moderately enriched, most likely by a previous subduction process (Zhai et al., 2004). Whereas abundant arc-related Permo-Triassic activity is documented in the NQT, relatively little evidence for such activity is documented in the SQT. Wu and Lang (1990) reported Late Permian andesites and dacites in the SQT, which led Liu et al. (2011) to propose not only subduction to the north underneath the NQT but also to the south underneath the SQT.

Along the southern margin of the NQT the Nadigang Ri group is mainly composed of acid tuff, dacite, rhyolite and minor basaltic volcanic rocks ranging in age from 223 to $205 \mathrm{Ma}$ (Zhai and Li, 2007; Fu et al., 2008). These rocks show a trend from melt generated by melting of subducted slab (ca. 223-219 Ma) to melting of Proterozoic oceanic crust (ca. 215-205 Ma; Zhai et al., 2013a). Bimodal activ- ity continued to $\sim 177 \mathrm{Ma}$ (Zhang et al., 2011) and includes the intrusion of the Gangtang Co granite at $\sim 210 \mathrm{Ma}$ (Kapp et al., 2003b; Hu et al., 2012). Granite samples from Gangtang Co granite (unpublished data) show a deep Eu anomaly as normalised to EMORB or OIB and show REE contents similar to OIB-derived melts. Some trace element concentrations, such as $\mathrm{Ta}, \mathrm{Yb}, \mathrm{Nb}, \mathrm{Y}$ and $\mathrm{Rb}$, suggest granite formation in a syn-collisional volcanic arc environment. The mafic lavas were probably derived from the mantle, whereas the felsic lavas were probably derived from partial melting of the continental crust in response to the asthenospheric upwelling (Zhang et al., 2011).

\section{Structures and tectonics of the mélange in mapping area}

Although there are abundant data on stratigraphy and igneous activity in the area, only a few (and contradicting) structural analyses have been published so far (e.g. Kapp et al., 2003; Pullen et al., 2011; Liang et al., 2012; Zhao et al., 2014). Below we present the results of detailed mapping in conjunction with 3-D modelling using satellite images and the program 3-D Move ${ }^{\mathrm{TM}}$ by Midland Valley. The false-colour ASTER images proved to be very useful, as different units can be recognised clearly and mapped in inaccessible areas after ground-truthing in mapped areas. The high topography also allows orienting the main structures and faults on the large scale.

The large-scale structure was modelled for three areas: SE of Mayigang Ri, NW of Rongma and NE of Jiaomu Ri (Fig. 5; see Fig. 1a for locations). The block diagrams show that the various units form a large-scale fold-and-thrust belt. Precambrian basement, exposed at Mayigang Ri, forms a flat-lying, N-dipping sheet that overlies a sheet of sedimentary mélange, separated by a $\sim 5-20^{\circ} \mathrm{NE}$-dipping fault gouge (Fig. 6a). The upper few tens of metres of the underlying sedimentary mélange are strongly sheared with a top-tothe-south sense of shear. The sedimentary mélange is itself underlain by ophiolitic mélange. Lithologies and main foliations are approximately parallel and follow the contacts between the various units, interpreted as thrusts. All units and main foliation are folded with shallowly plunging, EWstriking fold axes (Fig. 5). To the south, north of Gangtang $\mathrm{Co}$, the ophiolitic mélange is thrust over N-dipping Precambrian basement and slivers of Ordovician slate (Figs. 5, 6c). Unfortunately, most of this area is covered by Tertiary sediments.

West of Rongma, NE-dipping ophiolitic mélange overlies Precambrian basement and Ordovician and Carboniferous sediments (Fig. 6b). The main and only foliation in these latter units, as well as the second foliation $\left(S_{b 2}\right)$ in the underlying basement rocks, dips to the NE and increases in intensity towards the contact. The contact itself was initially a ductile shear zone that was overprinted by brittle deformation, as mylonitic rocks are found as clasts in brittle brec- 


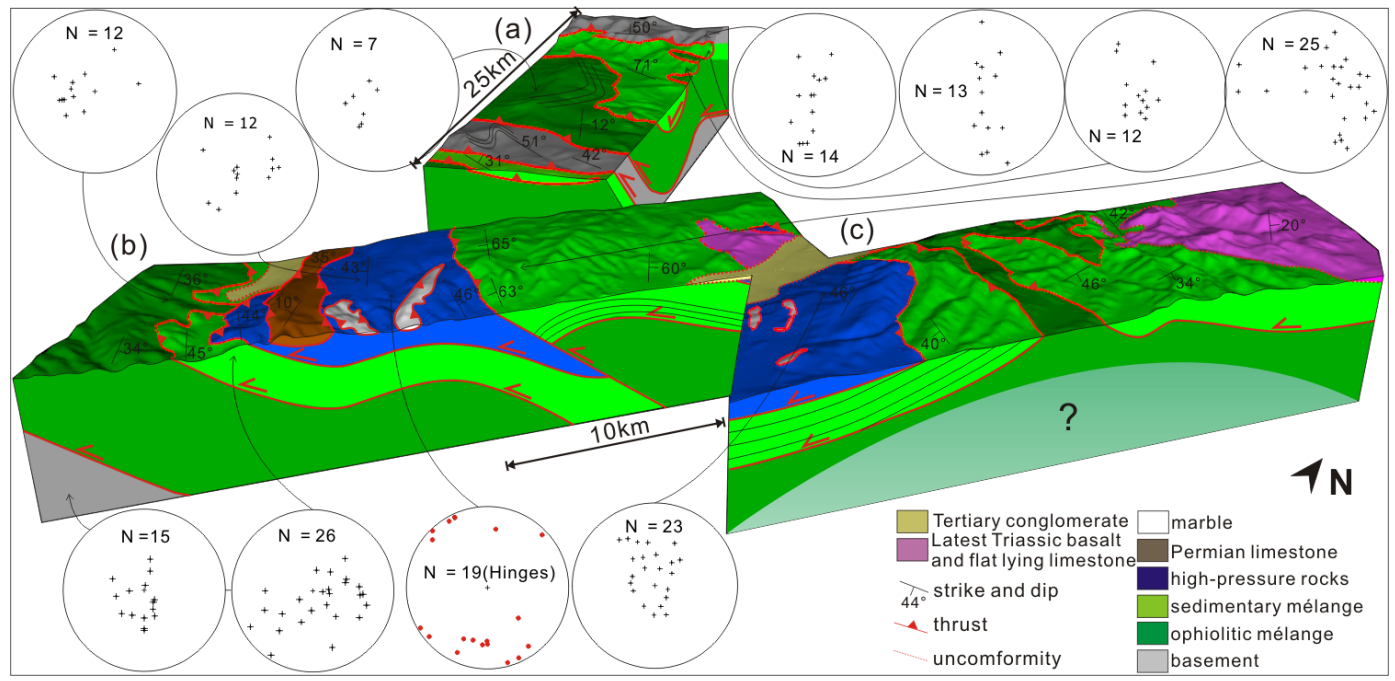

Figure 5. Three-dimensional reconstruction of selected areas near Rongma in the centre of the area showing the fold-and-thrust geometry of the three main sheets: basement, ophiolitic mélange and sedimentary mélange together with high-pressure rocks and rafts of (Permian) sediments. These are unconformably overlain by Late Triassic sediments: (a) south of Mayignag Ri, (b) northeast of Rongma and (c) northeast of Jiaomu Ri (see Fig. 1b). Lower-hemisphere equal-area stereoplots show the distribution of the main foliations (black crosses), as well as orientations of fold axes (red dots).

cias. Sigmoidal clasts in Ordovician sediments indicate a topto-the-south shearing (Fig. 3g). To the east, the ophiolitic mélange is overlain by a sheet of sedimentary mélange followed by a sheet of blueschists that contains marble lenses. The blueschists are gently folded around NS-striking fold axes. The strongly deformed high-pressure rocks are overlain by a sheet of non-metamorphic and relatively undeformed Permian limestones. The sequence of ophiolitic mélange, sedimentary mélange and blueschists is repeated again towards Jiaomo Ri. The shallow-dipping blueschists clearly overlie the sedimentary mélange (Fig. 6d).

The large-scale structure of the area is thus a fold-andthrust belt of, from bottom to top, Qiangtang basement (Precambrian to Carboniferous), ophiolitic mélange and finally juxtaposed sedimentary mélange, blueschists and rafts of Permian sediments. All these units have a dominant tectonic foliation that is approximately parallel to the main lithological boundaries. This foliation is the second foliation $\left(\mathrm{S}_{\mathrm{b} 2}\right)$ in the Precambrian basement (Fig. 3h), the first in the Carboniferous and Ordovician sediments $\left(\mathrm{S}_{\mathrm{O} 1}\right.$, Fig. $\left.3 \mathrm{~g}\right)$ and the main one $\left(S_{\mathrm{m} 1}\right)$ in the mélanges, which wraps around lenses and clasts. The parallelism of these foliations between the different units and with the main sheets indicates that they all formed during the thrusting event that created the stack of sheets. This is confirmed by $\mathrm{S}_{\mathrm{o} 2}$ west of Rongma, which is approximately parallel to bedding, causing boudinage and locally south-vergent isoclinal folding (Fig. 3i). It increases in intensity towards the mylonitic/breccia contact with the overlying ophiolitic mélange, as is to be expected if $\mathrm{S}_{\mathrm{o} 2}$ had been formed during thrusting of that mélange over the basement.
The $\sim 8 \mathrm{~km}$ thick stack of sheets is folded and thrusted on the $>10 \mathrm{~km}$ scale. The thickness of the stack, here derived from mapping and structural reconstructions, is confirmed by seismic data of Lu et al. (2013) and Li et al. (2013). The strike of the thrusts rotates from EW in the north towards NS in the east. In the southern part of the area folding and thrusting is south-vergent again (Fig. 5). This variation in trends is interpreted as the result of later doming of the central Qiangtang Culmination, which may have occurred as late as the Jurassic (Kapp et al., 2003a). Late Triassic limestones and overlying basalts discordantly overlie the sedimentary mélange and blueschists. These Triassic units are almost undisturbed and undeformed and shallowly dip to the east. The absence of equivalent Late Triassic sediments further west may be because these were never deposited here or because of the aforementioned doming, with the upper units now removed by erosion. The discordant contact between Late Triassic layers and underlying mélange and blueschists, as well as the lack of deformation in the Late Triassic layers, is evidence that sheet-parallel thrusting happened before the $\sim 210 \mathrm{Ma}$ Triassic sedimentation.

Further evidence is the fact that the undeformed $210 \mathrm{Ma}$ Gangtang Co granite is in intrusive contact with basement rocks and ophiolitic mélange and clearly cuts the contact between these two units (Fig. 1b; Zhao et al., 2014). Formation of the sheet stack can thus be constrained to have occurred between about $220 \mathrm{Ma}$ (Ar-Ar age of blueschists; Zhai et al., $2011 \mathrm{a}, \mathrm{b})$ and $210 \mathrm{Ma}$, which is the age of the granite intrusion and onset of Late Triassic sedimentation.

Timing of the folding and thrusting of the sheet stack is less clear. Folding of Late Triassic and Jurassic units in the 

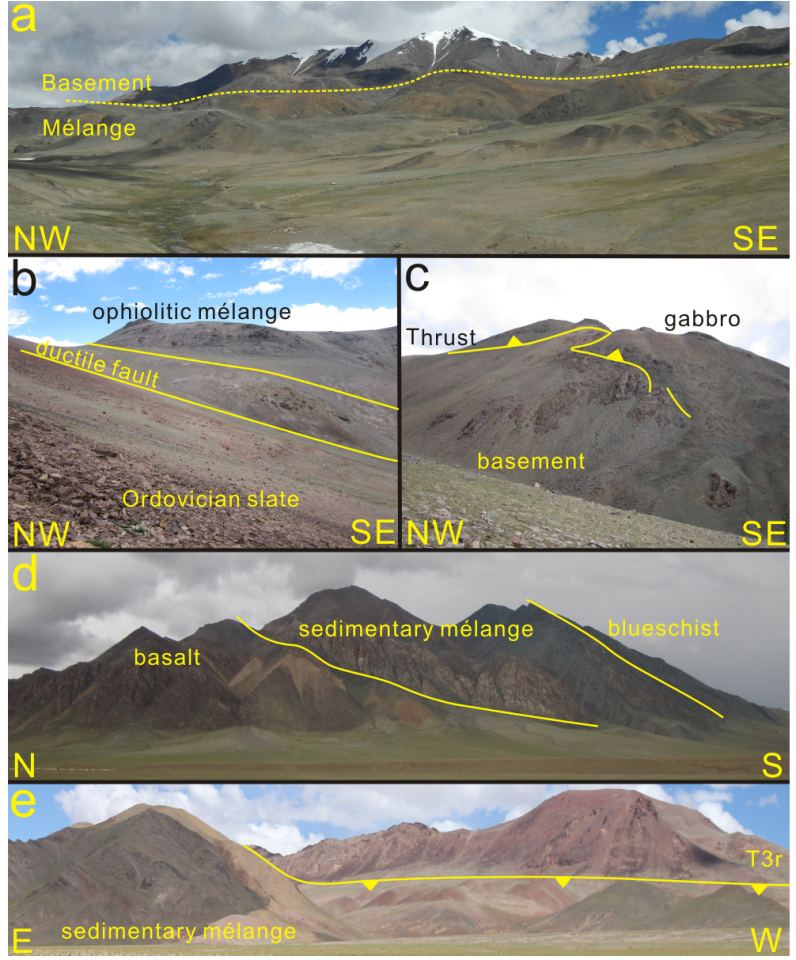

Figure 6. Field relationships of the main units. (a) View to the NW towards the Mayigang Ri Thrust, which thrusted basement on top of sedimentary mélange. (b) West of Rongma, ophiolitic mélange is thrusted on top of basement and Ordovician sediments, now separated by a wide fault zone. (c) Folded thrust that placed gabbros of the ophiolitic mélange on top the basement, north of Gangtang Co. (d) View from the north towards Jiaomu Ri, clearly showing that blueschists lie above the sedimentary mélange, which in turn overlies basalts of the ophiolitic mélange. (e) North-dipping thrust places subduction mélange over Late Triassic limestone $\left(\mathrm{T}_{3} \mathrm{r}\right)$ in the south of the study area, showing that at least part of the thrusting postdated the Late Triassic.

south of the area and even occasional folding of Tertiary conglomerates are clear evidence for Mesozoic to Tertiary tectonic activity (Kapp et al., 2005). Late Triassic sedimentation commenced earlier in the south than in the north of the SQT terrane. This suggests the presence of a foreland basin or depression in front of the thrust belt (Fig. 6e), with sedimentation progressively extending to the north as erosion flattened the topography. It cannot be excluded that the fold and thrust belt, at least in part, occurred in the Late Triassic.

\section{Discussion}

\subsection{Summary of main events and structures}

Any model for the tectonic evolution of the Qiangtang terrane(s) must take the following observations into account:

1. The SQT is a continental terrane with Gondwana affinity (Dong et al., 2011; Zhao et al., 2014) that comprises a Precambrian basement that is unconformably overlain by Ordovician to Middle Permian sediments.

2. Subduction-related igneous activity in the NQT ranges in age from 275 to $248 \mathrm{Ma}$ (Yang et al., 2011; Zhang et al., 2013) and is attributed to subduction of the PaleoTethys to the north at the Shuanghu suture (Yang et al., 2011) or alternatively to southward subduction of the Paleo-Tethys towards the south at the JSS suture (Wang et al., 2008b). Equivalent igneous activity is rare in the SQT. Both the NQT and SQT saw bimodal igneous activity, ranging in age from 236 to $177 \mathrm{Ma}$, with signatures indicating mafic underplating and ensuing crustal melting (Zhang et al., 2011). Most authors attribute this to some form of slab break-off (Zhai and Li, 2007; Zhang et al., 2011; Peng et al., 2014).

3. Although all workers agree that high-pressure rocks and subduction-related mélange crop out in the centre of the Qiangtang terrane, there is no agreement on the extent and classification of the various rocks. According to some authors, most of the area under consideration is a single "metamorphic belt" (e.g. Zhang et al., 2011), which ignores the fact that many rocks in this area are not metamorphic. Furthermore, metamorphism in the Precambrian rocks is pre-Ordovician (Zhao et al., 2014) and is unrelated to the Triassic high-pressure metamorphism of the blueschists. An opposite view is taken by Kapp et al. (2003b), who restrict the mélange to greenschist- to blueschist-facies rocks and classify the other, non-metamorphic rocks as part of the overlying Qiangtang continental crust. However, in our view this restricts the definition of mélange in the area too much, as large areas are mélange but not metamorphic. Based on our mapping, we define three main mélange lithologies: an ophiolitic and a sedimentary mélange, both notmetamorphosed (but carrying metamorphic inclusions), and a high-pressure unit.

4. The ophiolitic mélange consists of a range of sediments and abundant gabbros and basalts. A coherent oceanic crust sequence is, however, not observed. Ages of the mafic rocks range from Ordovician to Triassic.

5. The high-pressure rocks experienced peak metamorphic conditions at $\sim 240 \mathrm{Ma}$ and exhumed between 220 and $210 \mathrm{Ma}$, giving a minimum exhumation rate of $>1 \mathrm{~cm} \mathrm{yr}^{-1}$ (Zhai et al., 2011b).

6. In the Rongma area, the main units form a stack of sheets with Precambrian to Carboniferous basement at the base, ophiolitic mélange in the middle and sedimentary mélange with large rafts of blueschists and nonmetamorphic Permian sediments towards the top.

7. Formation of the sheet stack by S- to SW-thrusting took place between about 220 and 210 Ma. It was postdated 
by intrusion of the undeformed, $210 \mathrm{Ma}$ Gangtang Co granite and onset of Late Triassic sediment deposition and volcanic activity.

8. The sheet stack was folded and thrusted, again in an S to SW direction. Timing is uncertain and can range from the Late Triassic to the Mesozoic.

\subsection{Existence of a Paleo-Tethys ocean and direction of subduction}

The first question that needs to be addressed is whether the north and south Qiangtang are individual terranes that were separated by an ocean or not. One argument for the presence of this ocean is that glacial deposits and cold-water fauna indicate that the south Qiangtang terrane remained at high southern latitudes until the Middle Permian. However, only Upper Permian warm-water sediments are found in north Qiangtang terrane. It is thus possible that the north and south Qiangtang terranes moved into warmer regions together between the Middle and Late Permian. As was discussed by Pullen et al. (2014), cold- and warm-water faunas in the NQT and SQT neither prove nor disprove a separation of the two terranes.

Most authors invoke Permo-Triassic arc-related igneous activity, mainly in the NQT, as evidence for the former existence of the Shuanghu-Tethys between the NQT and SQT (Yang et al., 2011; Zhai et al., 2011a; Zhang et al., 2013; Peng et al., 2014). With few exceptions (Wang et al., 2008b), these authors interpret the igneous activity to result from northward subduction of this ocean underneath the NQT. Further indications for a former ocean between the NQT and SQT are the ophiolitic mélange and high-pressure rocks with oceanic affinity (Zhai et al., 2007; 2013a) in the SQT. However, Pullen and Kapp (2014) favour a southward subduction of the JSS-Tethys underneath a single Qiangtang terrane. The main argument for this is that in their structural interpretation, the subduction mélange in the Qiangtang terrane lies underneath the continental crust and was later exhumed by doming and normal faulting. The question is thus whether the mélange lies below or above continental crustal rocks. Several arguments are in favour of the latter. If the mélange was below the crust, it came from a depth of at least $35 \mathrm{~km}$ (Kapp et al., 2003b) and all mélange rocks must be metamorphic. This is not the case. Even with the restrictive definition of mélange in the map of Kapp et al. (2003b), areas mapped as greenschist are not all metamorphosed (Fig. 3a-e). As not all mélange rocks are metamorphic, they cannot all have come from a depth of tens of kilometres, as required in the underthrust model. Furthermore, this model requires a very shallow subduction angle for the subduction mélange to be at a relatively shallow depth $200 \mathrm{~km}$ south of the suture. This cannot explain the subduction-related igneous activity only in the north, close to the postulated suture. Finally, our mapping and structural interpretation clearly favours emplacement of the mélange on top of the continental crust (Fig. 5). If, as argued here, the mélange and high-pressure rocks were not exhumed by core-complex-like doming, their presence within the SQT is difficult to reconcile with any model other than the former presence of an ocean between the NQT and SQT.

\subsection{Models for exhumation of high-pressure rocks}

The presence of high-pressure rocks is one of the arguments to invoke subduction to the south or north of the NQT. The southward underthrust model of Kapp et al. (2003b) provides a clear mechanism of exhumation of the high-pressure rocks: metamorphic core-complex-like doming. This requires all mélange to have experienced high-pressure conditions, which contradicts our findings. The sequence of basement rocks at the base, overlain by ophiolitic mélange and high-pressure rocks, sedimentary mélange and sediments, cannot be reconciled with the proposed exhumation in a core complex, in which the autochthonous basement rocks should lie above the mélange.

Proponents of the northward subduction of a ShuanghuTethys underneath the NQT do not provide detailed mechanisms on the exhumation of the high-pressure rocks. Most authors propose high-pressure metamorphism at the downgoing slab, with subsequent exhumation in the orogenic wedge, possibly related to slab break-off (e.g. Zhang, 2006a; Li et al., 2009; Liu et al., 2011; Yang et al., 2011; Zhai et al., 2011a, b, 2012; Tang and Zhang, 2013). One problem with this exhumation in a convergent setting is that it should be related to extensive erosion during exhumation, which appears inconsistent with the regional sedimentary record (Pullen and Kapp, 2014). Exhumation of highpressure rocks in the orogenic wedge also does not explain how the high-pressure rocks are brought into contact with non-metamorphic sediments and sedimentary mélange as is observed in the Rongma area.

\subsection{Proposed tectonic evolution}

Below we provide an overview of the sequence of tectonic events that affected the Qiangtang area. The model we propose aims to explain our observations made in the study area and those published in the literature. Of particular relevance are the following: (1) the NQT and SQT were separated by an ocean of unknown width; (2) the high-pressure rocks and tectonic mélange are found in a fold-and-thrust belt of a stack of three sheets - basement rocks, ophiolitic mélange and sedimentary mélange - together with HP rocks and undeformed Permian sediments; (3) mafic rocks in the ophiolitic mélange range in age from the Ordovician to the Triassic. A key observation that needs to be explained is that the exhumed highpressure rocks were brought into direct contact with originally overlying non-metamorphic sediments and mélange. 


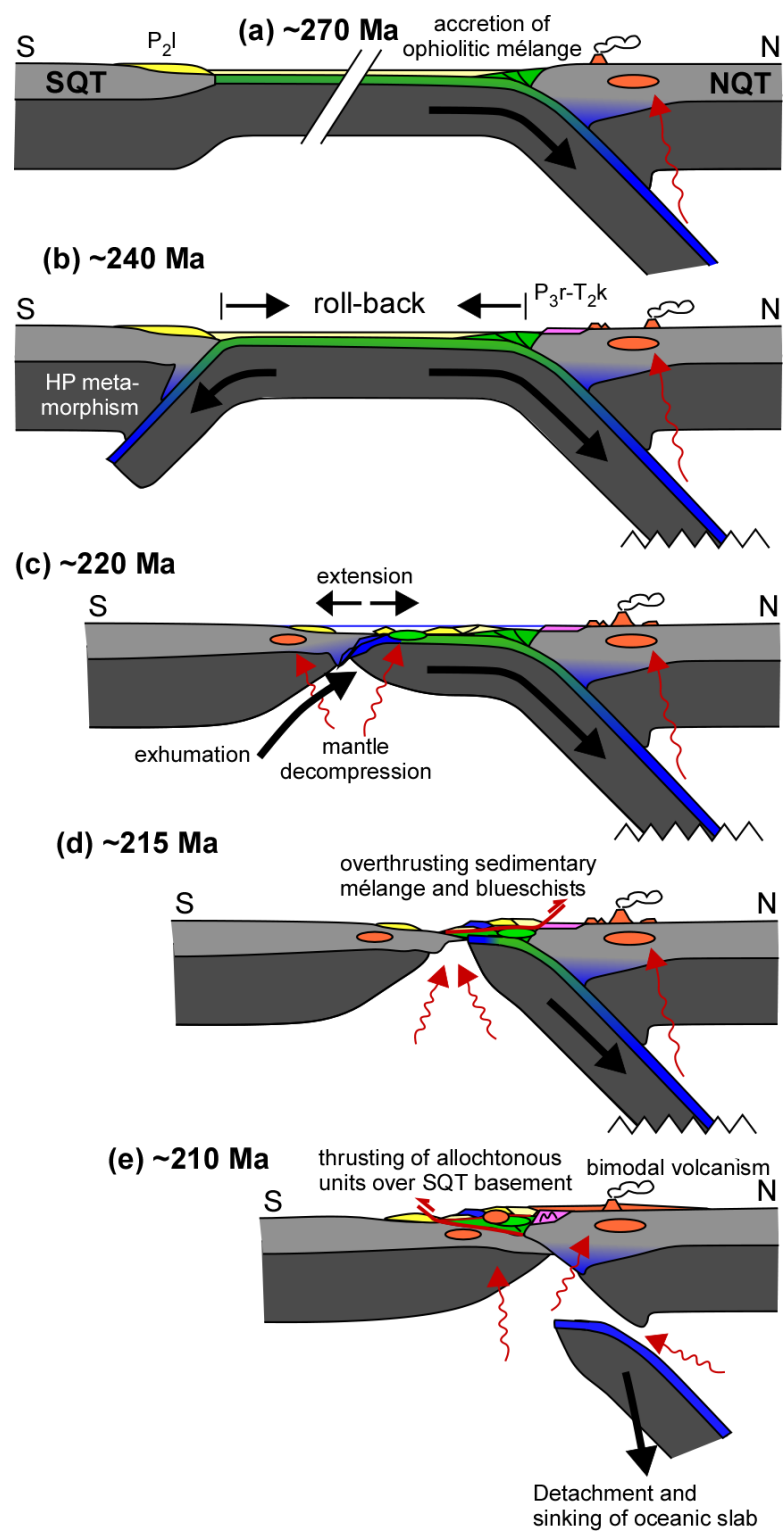

Figure 7. Schematic drawings of the Permian to Early Jurassic geological evolution of the Shuanghu-Tethys. Ages shown in the drawings are approximate only. (a) Northward subduction of the Shuanghu-Tethys underneath the NQT started at about $275 \mathrm{Ma}$. (b) Minor southward subduction would have commenced in the Early Triassic, necessitating rollback and convergence of the NQT and SQT. (c) Interaction between the converging subduction zones led to extraction of the short southern slab and concomitant exhumation of high-pressure rocks. These are brought in contact with surface-derived margin sediments and basement in a strongly extensional setting. (d) With ongoing convergence of the NQT and SQT, the sedimentary mélange (with high-pressure rocks) is thrust on top of the ophiolitic mélange at the LSS suture. (e) Ophiolitic and sedimentary mélange are ultimately thrust onto the SQT upon final collision of the two terranes. Asthenospheric upwelling leads to bimodal igneous activity on both sides of the Shuanghu-Tethys suture zone.

\subsubsection{Pre-Ordovician (> 470 Ma)}

The pre-Ordovician clastic metasediments form the oldest and structurally lowest unit of the Qiangtang basement. These rocks experienced low-grade metamorphism and one stage of deformation, leading to folding and the formation of the first cleavage $\left(S_{b 1}\right)$. This event is tentatively attributed to the Bhimphedian Orogeny (Cawood, 2007), when the basement rocks still formed part of (assembling) Gondwana (Zhao et al., 2014).

\subsubsection{Ordovician to Permian (470-270 Ma)}

Opening of the Shuanghu-Tethys between the NQT and the SQT probably commenced in the (Late) Ordovician. The SQT formed the passive northern margin of Gondwana on which sediments were deposited at various stages from the Ordovician to the Permian. Exposures of the Sumdo eclogites in the Lhasa terrane may indicate that the SQT and north Lhasa terrane together separated from Gondwana as early as the Carboniferous (Yang et al., 2009). Initial rifting and subsequent ocean spreading produced mafic rocks with ages ranging from the Ordovician to the Permian in central Qiangtang (Zhai et al., 2010, 2012, 2013).

\subsubsection{Upper Permian to Lower Triassic (270-240 Ma)}

Northward subduction of the Paleo-Tethys underneath the NQT commenced at $\sim 275 \mathrm{Ma}$, as is indicated by arc activity in the NQT (Yang et al., 2012; Fig. 7a). The youngest known passive margin sediments $\left(\mathrm{P}_{2} \mathrm{l}\right)$ were deposited on the SQT, but no known sedimentation occurred at the active southern margin of the NQT where arc volcanism occurred instead. Ocean-floor sediments and mafics from the oceanic crust were accreted to the NQT: the future ophiolitic mélange (Zhai et al., 2010, 2012, 2013). Although igneous activity indicates that most of the subduction occurred on the northern margin of the Shuanghu-Tethys, the southern margin, with cold, > 100-million-year-old oceanic crust, would probably also have started to subduct (Fig. 7b; Liu et al., 2011). This would have brought oceanic crust and material from lower crust of the overriding SQT plate down to $>100 \mathrm{~km}$ by $\sim 240 \mathrm{Ma}$, which is the age of peak metamorphism in the high-pressure rocks (Pullen et al., 2011).

\subsubsection{Middle Triassic (240-220 Ma)}

With (minor) subduction to the south as well, the ShuanghuTethys plate would have formed a divergent double subduction zone (Gray and Foster, 2004; Soesoo et al., 1997; Zhao, 2015) with a long slab subducting to the north and a short one to the south. A divergent double subduction zone was proposed for the Shuanghu-Tethys by Liu et al. (2011). As long as the two sutures are far enough apart, each operates independently from the other. In the absence of spreading in-between, the two sutures must converge by rollback. This 
inevitably leads to the two sutures converging to the point where the slab pull of one subduction zone starts to affect the other. At some point in this scenario, the slab pull of the long (northern) slab will override the opposite pull of the short (southern) slab, which results in the short one being pulled up and towards the north (Fig. 7c). This scenario is similar to the current situation of the Adria plate, which subducts underneath Italy (short slab) and the Dinarides (long slab; Gvirtzman and Nur, 2001; Di Stefano et al., 2009; Giacomuzzi et al., 2012). The Adria plate now moves as a whole towards the Dinarides, causing rapid extension east of the Apennines (Devoti et al., 2008; Weber et al., 2010). The proposed model for exhumation of high-pressure rocks in a divergent double subduction zone is novel but bears some similarities with models for exhumation by slab rotation (Hacker et al. 2000; Webb et al., 2013) or slab eduction (Andersen et al., 1991; Duretz et al., 2012; Brueckner and Cuthbert, 2013). The main difference is that we suggest that the pull of the longer slab is the driving force for slab extraction and resulting exhumation of high-pressure rocks. Extraction of the slab from underneath the SQT causes extension of its margin, while high-pressure rocks exhume. Trench and Permian margin sediments are dragged off the margin and brought in contact with the exhumed high-pressure rocks from below to form the observed association of sedimentary mélange, rafts of Permian sediments and blueschists. All these rocks, as well as the SQT Precambrian to Carboniferous basement are expected to experience strong flattening strain due to the extension, as well as a top-to-south shearing. This is consistent with the $\mathrm{D}_{2}$ deformation in basement rocks $\left(\mathrm{S}_{\mathrm{b} 2}, \mathrm{~S}_{\mathrm{o} 1}\right)$ and main foliation in the sedimentary mélange $\left(\mathrm{S}_{\mathrm{m} 1}\right)$. It should be noted that this core-complex-like extension is to some extent similar to that proposed by Kapp et al. (2003b) with the difference being that we propose the whole oceanic slab, not only the mélange, to form the core of the complex. The structural relationships are in part similar as described by these authors: low-grade rocks juxtaposed onto high-pressure rocks in a strongly extensional setting.

A second effect of the extraction of the short slab is rising of the asthenosphere, with resulting mafic igneous activity, as well as melting of the crust, producing felsic melts. In the SQT, bimodal activity is documented from $\sim 236 \mathrm{Ma}$ (Zhang et al., 2011). Liu et al. (2011) showed that exhumation of the high-pressure rocks was approximately isothermal $\left(\sim 500^{\circ} \mathrm{C}\right)$ down to at least $\sim 7 \mathrm{kbar}$, suggesting rapid exhumation that is in accordance with the proposed model. Juxtaposition of the still relatively hot exhuming blueschists and non-metamorphic sedimentary mélange and sediments can explain the formation of epidote, tremolitic amphibole and garnet-bearing marbles at the contact (Fig. 4). Additional heating may have been related to mantle upwelling and concomitant igneous activity.

\subsubsection{Middle-Upper Triassic (220-200 Ma)}

Northward movement of the Shuanghu-Tethys plate, during convergence of the NQT and SQT, carried the mix of sedimentary mélange and high-pressure rocks northward, towards and in the end on top of the accreted material at the northern suture, the ophiolitic mélange (Fig. 7d). As the two terranes collided, all these rocks were thrusted onto the SQT, producing the sheet stack as is now observed. At this stage, the Shuanghu-Tethys slab finally slid down into the mantle, giving rise to a last stage of asthenosphere upwelling and resulting bimodal igneous activity, including the 210 Ma Gangtang Co granite and Upper Triassic rhyolites and basalts, mostly in the north but also extending south onto the (former) SQT (Fig. 7e). Post-collisional sediments, intercalated with volcanics, cover the amalgamated Qiangtang terrane. From south to north, these Upper Triassic deposits show two trends: from shallow marine, carbonate-dominated sediments towards terrestrial fluvial sediments and an increasing amount of bimodal volcanic deposits. This can be interpreted as a foreland basin that developed in the south in front of the thrust belt in the north. Southward propagation of thrusting finally thrusted mélange and $\mathrm{P}_{2} 1$ in the hanging wall against latest Triassic sediments in the footwall (Fig. 6e).

\subsubsection{Jurassic (200-170 Ma)}

Following the closure of Longmu Co-Shuanghu suture zone, the Bangong-Nujiang suture zone opened between the amalgamated Qiangtang terrane and the north Lhasa terrane. Jurassic shallow marine deposits unconformably overlie Late Triassic $\mathrm{T}_{3} \mathrm{n}$ sediments and volcanics on the NQT. Jurassic the deep-water flysch sediments $\left(\mathrm{J}_{1-2} \mathrm{~s}\right)$ cover all the older units in the southern SQT. These are thought to represent the opening of the Bangong-Nujiang suture zone (Schneider et al., 2003; Baxter et al., 2009). It is not known whether Jurassic sediments once covered the whole Qiangtang terrane or they were never deposited there. Jurassic sediments, if once present, could have been removed during formation of the central Qiangtang Culmination. This domal structure may have formed as early as the Jurassic (Kapp et al., 2005) or during compressional stages resulting from the closure of the Meso- and Neo-Tethys during the Cretaceous and Paleogene respectively (Kapp et al., 2007; Xu et al., 2014). Minor terrestrial sediments, mostly conglomerates in fault-bounded basins, were deposited during the Cretaceous and Tertiary.

\section{Conclusions}

Subduction mélange and high-pressure rocks in the Qiangtang terrane record an important stage in the evolution and formation of the Tibetan Plateau, which has consequences for the location of different former oceans. Our mapping and structural analysis of the Rongma area in the centre of the metamorphic belt leads to the following main conclusions: 
1. The north and south Qiangtang terranes were formerly separated by an Ordovician-Triassic ocean. Metamorphism in the central Qiangtang metamorphic belt occurred in two unrelated stages. The first, a lower greenschist-facies event, occurred in pre-/earlyOrdovician times and affected the Precambrian basement. A second event produced the high-pressure rocks that exhumed in the Triassic as a result of the closure at the Longmu Co-Shuang Hu suture zone between the north and south Qiangtang terranes.

2. The pre- to syn-collision lithologies (>210 Ma) can be grouped into three main units: (1) carboniferous and older basement, (2) non-metamorphic ophiolitic mélange and (3) non-metamorphic sedimentary mélange with large rafts and sheets of non-metamorphic Permian sediments and high-pressure rocks (mostly blueschists).

3. To explain the current structural relationships of the units, we propose that the high-pressure rocks were exhumed by extraction of a short, south-dipping slab from underneath the south Qiangtang terrane, bringing them in contact with the sedimentary mélange and Permian margin sediments. This unit was subsequently thrusted on top of the ophiolitic mélange. Upon final collision of the north and south Qiangtang terranes, both units were placed on top of the Paleozoic south Qiangtang basement. The whole tripartite stack was subsequently further shortened into a south-verging fold and thrust belt. This may have been a consequence of the amalgamation of the two terranes or later (Jurassic-Paleogene) events.

4. After closure of the Longmu Co-Shuanghu suture zone, Upper Triassic sedimentation commenced in the south in a foreland setting and progressively extended to the north where extensive bimodal volcanic activity occurred, which is interpreted as the result of mantle upwelling due to the final sinking of the Paleo-Tethys slab. This study is based on a large study area in the centre of the Qiangtang terrane, which extends over almost $2000 \mathrm{~km}$. We hope that this study encourages more work, including detailed mapping and structural analysis, in the whole terrane to confirm or reject the former presence of an ocean between the north and south Qiangtang terranes as well as investigate the consequences in terms of presence and size of other oceans between the various terranes that form the Tibetan Plateau.

Author contributions. Fieldwork was carried out by G. Wang and his team, including Y. Liu and Z. Zhao. Structural interpretations, modelling and thin section analyses were carried out by $Z$. Zhao and P. D. Bons. A. Soesoo scrutinised the geochemical data. The paper was written by all authors.
Acknowledgements. This research was funded by the China $\mathrm{Ge}-$ ological Survey (CGS) through the 1:50 000 regional geological surveys in the Qomo Ri, Gangmari and Rongma areas of Tibet as well as project 1212011121271, titled "Tectonic attributes of the south Qiangtang Mesozoic-Cenozoic basin, based on deformation and metamorphic character". Additionally, we appreciate the Program for Changjiang University Scholars and Innovative Research Teams (IRT1083). Z. Zhao thanks the Chinese Scholarship Council for financial support. We thank the whole mapping team of the China University of Geosciences, Beijing. We appreciate the helpful comments and criticism of two anonymous reviewers. We also thank Thomas Wenzel for his advice on petrology.

Edited by: T. Gerya

\section{References}

Agard, P., Yamato, P., Jolivet, L., and Burov, E.: Exhumation of oceanic blueschists and eclogites in subduction zones: timing and mechanisms, Earth-Sci. Rev., 92, 53-79, 2009.

Andersen, T. B., Jamtveit, B., Dewey, J. F., and Swensson, E.: Subduction and eduction of continental crust: major mechanism during continent-continent collision and orogenic extensional collapse, a model based on the south Caledonides, Terra Nova, 3, 303-310, 1991.

Baxter, A. T., Aitchison, J. C., and Zyabrev, S. V.: Radiolarian age constraints on Mesotethyan ocean evolution, and their implications for development of the Bangong-Nujiang suture, Tibet, J. Geol. Soc. London, 166, 689-694, 2009.

Brueckner, H. K. and Cuthbert, S. J.: Extension, disruption, and translation of an orogenic wedge by exhumation of large ultrahigh-pressure terranes: Examples from the Norwegian Caledonides, Lithosphere, 5, 277-289, 2013.

Bucher, K. and Frey, M.: Petrogenesis of metamorphic rocks, 7th Edn., Springer, Berlin-Heidelberg, Germany, 259-277, 2002.

Cawood, P. A., Johnson, M. R., and Nemchin, A. A.: Early Palaeozoic orogenesis along the Indian margin of Gondwana: Tectonic response to Gondwana assembly, Earth Planet Sc. Lett., 255, 7084, 2007.

Chen, S., Cheng, L., Wu, S., and Zhu, Y.: Late Permian fusulinds from the Raggyorcaka Formation, northern Qiangtang, Tibet, China, Geological Bulletin of China, 28, 1725-1729, 2009.

Devoti, R., Riguzzi, F., Cuffaro, M., and Doglioni, C.: New GPS constraints on the kinematics of the Apennines subduction, Earth Planet. Sc. Lett., 273, 163-174, 2008.

Dewey, J. F., Shackleton, R. M., Chengfa, C., and Yiyin, S.: The tectonic evolution of the Tibetan Plateau, Philos. T. R. Soc. A, 327, 379-413, 1988.

Di Stefano, R., Kissling, E., Chiarabba, C., Amato, A., and Giardini, D.: Shallow subduction beneath Italy: Three-dimensional images of the Adriatic-European-Tyrrhenian lithosphere system based on high-quality P wave arrival times, J. Geophys. Res.-Sol Ea., 114, 1978-2012, 2009.

Dong, C., Li, C., Wan, Y., Wang, W., Wu, Y., Xie, H., and Liu, D.: Detrital zircon age model of Ordovician Wenquan quartzite south of Lungmuco-Shuanghu Suture in the Qiangtang area, Tibet: Constraint on tectonic affinity and source regions, Sci. China Ser. D, 54, 1034-1042, 2011. 
Duan, Z., Zhong, C., Zhu, H., Cheng, J., Li, Z., and Wang, Z.: Sedimentary characteristics of Middle Jurassic Sewa and Buqu Formations from Qiangzi Well-2, southern Qiangtang basin, Tibet, Geology in China, 36, 355-365, 2009.

Duretz, T., Gerya, T. V., Kaus, B. J. P., and Andersen, T. B.: Thermomechanical modelling of slab eduction, J. Geophys. Res.-Sol. Ea., 117, 1978-2012, doi:10.1029/2012JB009137, 2012.

Fu, X., Wang, J., Wang, Z., and Chen, W.: U-Pb Zircon Age and Geochemical Characteristics of Volcanic 5 Rocks from the Juhua Mountain Area in the northern Qiangtang Basin, northern Xizang (Tibet), Geological Review, 54, 232-242, 2008.

Fu, X., Wang, J., Tan, F., Chen, M., and Chen, W.: The Late Triassic rift-related volcanic rocks from eastern Qiangtang, northern Tibet (China): Age and tectonic implications, Gondwana Res., 17, 135-144, 2010a.

Fu, X., Wang, J., Wu, T., and He, J.: Stratigraphy and paleoenvironment of the Quemo Co Formation in Shengli River area, northern Tibet, Geology in China, 37, 1305-1312, 2010 b.

Giacomuzzi, G., Civalleri, M., De Gori, P., and Chiarabba, C.: A 3 -D vs. model of the upper mantle beneath Italy: Insight on the geodynamics of central Mediterranean, Earth Planet. Sc. Lett., 335, 105-120, 2012.

Gray, D. and Foster, D.: Tectonic evolution of the Lachlan Orogen, southeast Australia: historical review, data synthesis and modern perspectives, Aust. J. Earth Sci., 51, 773-817, 2004.

Gvirtzman, Z. and Nur, A.: Residual topography, lithospheric structure and sunken slabs in the central Mediterranean, Earth Planet. Sc. Lett., 187, 117-130, 2001.

Hacker, B. R., Ratschbacher, L., Webb, L. E., McWilliams, M., Ireland, T. R., Calvert, A., Dong, S., Wenk, H.-R., and Chateigner, D.: Exhumation of ultrahigh-pressure continental crust in eastcentral China: Late Triassic - Early Jurassic tectonic unroofing, J. Geophys. Res., 105, 13339-13364, 2000.

Hu, P., Li, C., Su, L., and Zhang, H.: Geochemical and 40Ar39Ar isotope chronological characteristics of Wugongshan IndoChinese granites in central Qiangtang, Tibetan Plateau, Geological Bulletin of China, 31, 843-851, 2012.

Kapp, P., Yin, A., Manning, C. E., Murphy, M., Harrison, T. M., Spurlin, M., Lin, D., Xi-Guang, D., and Cun-Ming, W.: Blueschist-bearing metamorphic core complexes in the Qiangtang block reveal deep crustal structure of northern Tibet, Geology, 28, 19-23, 2000.

Kapp, P., Murphy, M. A., Yin, A., Harrison, T. M., Ding, L., and Guo, J.: Mesozoic and Cenozoic tectonic evolution of the Shiquanhe area of western Tibet, Tectonics, 22, TC1029, doi:10.1029/2001TC001332, 2003a.

Kapp, P., Yin, A., Manning, C. E., Harrison, T. M., Taylor, M. H., and Ding, L.: Tectonic evolution of the early Mesozoic blueschist-bearing Qiangtang metamorphic belt, central Tibet, Tectonics, 22, 1043-1068, 2003b.

Kapp, P., Yin, A., Harrison, T. M., and Ding, L.: Cretaceous-Tertiary shortening, basin development, and volcanism in central Tibet, Bull. Geol. Soc. Am., 117, 865-878, 2005.

Kapp, P., DeCelles, P. G., Gehrels, G. E., Heizler, M., and Ding, L.: Geological records of the Lhasa-Qiangtang and Indo-Asian collisions in the Nima area of central Tibet, Bull. Geol. Soc. Am., 119, 917-932, 2007.
Li, C.: The Longmu Co-Shuanghu-Lancangjiang Suture as the northern boundary of the Gandwana land in the Carboniferous and Permian, Bull. Changcun Coll. Geol. Sci, 17, 155-166, 1987.

Li, C.: Geological map of the Myyi Gang Ri area (Scale at $1: 250000$ ), University of Jilin Region Institute of geological survey, China, 2006.

Li, X. and Wen, F.: Discovery of the Late Triassic Rigain Pünco Formation and the unconformity between it and its under lying strata in eastern Rutog, Tibet, China, Geological Bulletin of China, 26, 1009-1013, 2007.

Li, C., Cheng, L., Hu, K., Yang, Z., and Hong, Y.: Study on the paleo-Tethys suture zone of Lungmu Co-Shuanghu, Tibet, Geol. Publ. House, Beijing, China, 131 pp., 1995.

Li, C., Cheng, L., Zhang, Y., and Zhai, Q.: Discovery of OrdovicianDevonian strat in the south of the Qiangtang area, Tibet, Geological Bulletin of China, 23, 602-604, 2004

Li, C., Zhai, Q., Dong, Y., and Huang, X.: Discovery of eclogite and its geological significance in Qiangtang area, central Tibet, Chinese Sci. Bull., 51, 1095-1100, 2006.

Li, C., Zhai, Q., Dong, Y., Zeng, Q., and Huang, X.: Longmu CoShuanghu plate suture and evolution records of paleo-Tethyan oceanic in Qiangtang area, Qinghai-Tibet plateau, Frontiers of Earth Science in China, 1, 257-264, 2007.

Li, C., Zhai, Q., Dong, Y., Liu, S., Xie, C., and Wu, Y.: Highpressure eclogite-blueschist metamorphic belt and closure of paleo-Tethys Ocean in Central Qiangtang, Qinghai-Tibet plateau, J. Earth Sci., 20, 209-218, 2009.

Li, Q., Gao, R., Feng, X., Lu, Z., Hou, H., Ye, G., Li, P.,Wang, H., Ye, Z., and Xiong, X.: Structural Characteristics of the Basement beneath Qiangtang Basin in Qinghai-Tibet Plateau: Results of Interaction Interpretation from Seismic Reflection/Refraction Data, Acta Geol. Sin.-Engl., 87, 358-377, 2013.

Liang, X., Wang, G., Yuan, G., and Liu, Y.: Structural sequence and geochronology of the Qomo Ri accretionary complex, Central Qiangtang, Tibet: Implications for the Late Triassic subduction of the Paleo-Tethys Ocean, Gondwana Res., 22, 470-481, 2012.

Liu, Y., Santosh, M., Zhao, Z. B., Niu, W. C., and Wang, G. H.: Evidence for palaeo-Tethyan oceanic subduction within central Qiangtang, northern Tibet, Lithos, 127, 39-53, 2011.

Lu, Z., Gao, R., Li, Y., Xue, A., Li, Q., Wang, H., Kuang, C., and Xiong, X.: The upper crustal structure of the Qiangtang Basin revealed by seismic reflection data, Tectonophysics, 606, 171177, 2013.

Metcalfe, I.: Late Palaeozoic and Mesozoic tectonic and palaeogeographical evolution of SE Asia, Geol. Soc. SP, London, UK, 315 , 7-23, 2009.

Nie, S., Yin, A., Rowley, D. B., and Jin, Y.: Exhumation of the Dabie Shan ultra-high-pressure rocks and accumulation of the Songpan-Ganzi flysch sequence, central China, Geology, 22 , 999-1002, 1994

Peng, T., Zhao, G., Fan, W., Peng, B., and Mao, Y.: Late Triassic granitic magmatism in the Eastern Qiangtang, Eastern Tibetan Plateau: Geochronology, petrogenesis and implications for the tectonic evolution of the Paleo-Tethys, Gondwana Res., doi:10.1016/j.gr.2014.01.009, 27, 1494-1508, 2014.

Pullen, A. and Kapp, P.: Mesozoic tectonic history and lithospheric structure of the Qiangtang terrane: Insights from the Qiangtang metamorphic belt, central Tibet, Geol. S. Am. S., 507, 507-504, 2014. 
Pullen, A., Kapp, P., Gehrels, G. E., Vervoort, J. D., and Ding, L.: Triassic continental subduction in central Tibet and Mediterranean-style closure of the Paleo-Tethys Ocean, Geology, 36, 351-354, 2008.

Pullen, A., Kapp, P., Gehrels, G. E., Ding, L., and Zhang, Q.: Metamorphic rocks in central Tibet: Lateral variations and implications for crustal structure, Bull. Geol. Soc. Am., 123, 585-600, 2011.

Schneider, W., Mattern, F., Wang, P. J., and Li, C.: Tectonic and sedimentary basin evolution of the eastern Bangong-Nujiang zone (Tibet): A Reading cycle, Int. J. Earth Sci., 92, 228-254, 2003.

Şengör, A., Altıner, D., Cin, A., Ustaömer, T., and Hsü, K.: Origin and assembly of the Tethyside orogenic collage at the expense of Gondwana Land, Geol. Soc. Eng. Geol. Sp., 37, 119-181, 1988.

Soesoo, A., Bons, P. D., Gray, D. R., and Foster, D. A.: Divergent double subduction: tectonic and petrologic consequences, Geology, 25, 755-758, 1997.

Tang, X. and Zhang, K.: Lawsonite-and glaucophane-bearing blueschists from NW Qiangtang, northern Tibet, China: mineralogy, geochemistry, geochronology, and tectonic implications, Int. Geol. Rev., 56, 150-166, 2013.

Wang, J., Fu, X., Chen, W., and Wang, Z.: The Late Triassic Paleoweathering Crust in the Qiangtang Basin Northern Tibet: geology, geochemistry and significance, Acta Geol. Sin.-Engl., 25, 487-494, 2007.

Wang, J., Fu, X. G., Chen, W. X., Wang, Z. J., Tan, F. W., Chen, M., and Zhuo, J. W.: Chronology and geochemistry of the volcanic rocks in Woruo Mountain region, northern Qiangtang depression: Implications to the Late Triassic volcanic-sedimentary events, Sci. China Ser. D, 51, 194-205, 2008a.

Wang, Q., Wyman, D. A., Xu, J., 5 Wan, Y., Li, C., Zi, F., Jiang, Z., Qiu, H., Chu, Z., and Zhao, Z.: Triassic Nb-enriched basalts, magnesian andesites, and adakites of the Qiangtang terrane (Central Tibet): evidence for metasomatism by slab-derived melts in the mantle wedge, Contrib. Mineral. Petr., 155, 473-490, $2008 \mathrm{~b}$.

Wang, S., Li, Z., and Qiangba, X.: Geologic map and geologic report of the Xigaze area, Tibetan Bur. of Geol. and Miner. Resour., Llasa, China, 1983.

Webb, L. E., Baldwin, S. L., Little, T. A., and Fitzgerald, P. G.: Can microplate rotation drive subduction inversion?, Geology, 36, 823-826, 2008.

Weber, J., Vrabec, M., Pavlovcic-Preceren, P., Dixon, T., Jiang, Y., and Stopar, B.: GPS-derived motion of the Adriatic microplate from Istria Peninsula and Po Plain sites, and geodynamic implications, Tectonophysics, 483, 214-222, 2010.

Wu, G., Yao, J., and Ji, Z.: The Late Carboniferous Fusulinids in the central part of northern Qiangtang, Tibet,China, Geological Bulletin of China, 28, 1276-1280, 2009.

Wu, R. Z. and Lang, B. L.: The new strata data of the Late Permian in northwest Tibet, Journal of Stratigraphy (in Chinese with English abstract), 14, 216-221, 1990.

$\mathrm{Xu}$, M., Li, C., Zhang, X., and Wu, Y.: Nature and evolution of the Neo-Tethys in central Tibet: synthesis of ophiolitic petrology, geochemistry, and geochronology, Int. Geol. Rev., 56, 1-25, 2014.

Yang, J., Xu, Z., Li, Z., Xu, X., Li, T., Ren, Y., Li, H., Chen, S., and Robinson, P. T.: Discovery of an eclogite belt in the Lhasa block, Tibet: A new border for Paleo-Tethys?, J. Asian Earth Sci., 34, 76-89, 2009.
Yang, T., Zhang, H., Liu, Y., Wang, Z., Song, Y., Yang, Z., Tian, S., Xie, H., and Hou, K.: Permo-Triassic arc magmatism in central Tibet: Evidence from zircon U-Pb geochronology, Hf isotopes, rare earth elements, and bulk geochemistry, Chem. Geol., 284, 270-282, 2011.

Yin, A. and Harrison, T. M.: Geologic evolution of the HimalayanTibetan orogen, Annu. Rev. Earth Pl. Sc., 28, 211-280, 2000.

Yin, A. and Nie, S.: A Phanerozoic palinspastic reconstruction of China and its neighboring regions, The Tectonics of Asia, Cambridge Univ. Press, New York, USA, 442-485, 1996.

Zhai, Q. and Li, C.: Zircon SHRIMP dating of volcanic rock from Nadigangri Formation in Juhuashan, Qiangtang, Northern Tibet and its geological significance, Acta Geol. Sin.-Engl., 81, 795800, 2007.

Zhai, Q., Li, C., and Huang, X.: The fragment of Paleo-Tethys ophiolite from central Qiangtang, Tibet: Geochemical evidence of metabasites in Guoganjianian, Sci. China Ser. D, 50, 1302-1309, 2007.

Zhai, Q., Li, C., Cheng, L., and Zhang, Y.: Geological features of Permian ophiolite in the Jiaomuri area, Qiangtang, Tibet, and its tectonic significance, Regional Geology of China, 23, 12281229, 2004.

Zhai, Q., Li, C., Wang, J., Ji, Z., and Wang, Y.: SHRIMP U-Pb dating and $\mathrm{Hf}$ isotopic analyses of zircons from the mafic dyke swarms in central Qiangtang area, Northern Tibet, Chinese Sci. Bull., 54, 2279-2285, 2009.

Zhai, Q., Wang, J., Li, C., and Su, L.: SHRIMP U-Pb dating and Hf isotopic analyses of Middle Ordovician meta-cumulate gabbro in central Qiangtang, northern Tibetan Plateau, Sci. China Ser. D, 53, 657-664, 2010.

Zhai, Q., Jahn, B. M., Zhang, R.,Wang, J., and Su, L.: Triassic Subduction of the Paleo-Tethys in northern Tibet, China: evidence from the geochemical and isotopic characteristics of eclogites and blueschists of the Qiangtang Block, J. Asian Earth Sci., 42, 1356-1370, 2011a.

Zhai, Q., Zhang, R., Jahn, B. M., Li, C., Song, S., and Wang, J.: Triassic eclogites from central Qiangtang, northern Tibet, China: Petrology, geochronology and metamorphic PT path, Lithos, 125, 173-189, 2011b.

Zhai, Q.-G., Jahn, B.-M., Su, L., Wang, J., Mo, X.-X., Lee, H.-Y., Wang, K.-L., and Tang, S.: Triassic arc magmatism in the Qiangtang area, northern Tibet: Zircon U-Pb ages, geochemical and Sr-Nd-Hf isotopic characteristics, and tectonic implications, J. Asian Earth Sci., 63, 162-178, 2013a.

Zhai, Q., Jahn, B., Wang, J., Su, L., Mo, X., Wang, K., Suohan, T., and Lee, H.: The Carboniferous ophiolite in the middle of the Qiangtang terrane, Northern Tibet: SHRIMP U-Pb dating, geochemical and Sr-Nd-Hf isotopic characteristics, Lithos, 168, 186-199, 2013b.

Zhang, K. J.: Blueschist-bearing metamorphic core complexes in the Qiangtang block reveal deep crustal structure of northern Tibet: Comment, Geology, 29, p. 90, 2001.

Zhang, K. and Tang, X.: Eclogites in the interior of the Tibetan Plateau and their geodynamic implications, Chinese Sci. Bull., 54, 2556-2567, 2009.

Zhang, S., Wang, H., Feng, D., Jiang, X., Li, X., and Li, Q.: The Xiaochaka Group and Riganpeicuo Group stratigraphic sequence and correlation in the Qiangtang area, Tibet - question the valid- 
ity of the boundary between Qiangnan and Qiangbei strata, Jilin Geology, 24, 16-20, 2005.

Zhang, K., Cai, J., Zhang, Y., and Zhao, T.: Eclogites from central Qiangtang, northern Tibet (China) and tectonic implications, Earth Planet. Sc. Lett., 245, 722-729, 2006a.

Zhang, K., Zhang, Y., Li, B., Zhu, Y., and Wei, R.: The blueschistbearing Qiangtang metamorphic belt (northern Tibet, China) as an in situ suture zone: Evidence from geochemical comparison with the Jinsa suture, Geology, 34, 493-497, $2006 \mathrm{~b}$.

Zhang, K., Zhang, Y., Xia, B., and He, Y.: Temporal variations of Mesozoic sandstone compositions in the Qiangtang block, northern Tibet (China): implications for provenance and tectonic setting, J. Sediment. Res., 76, 1035-1048, 2006c.

Zhang, K. J. and Tang, X. C.: Eclogites in the interior of the Tibetan Plateau and their geodynamic implications, Chinese Sci. Bull., 54, 2556-2567, 2009.

Zhang, K., Tang, X., Wang, Y., and Zhang, Y.: Geochronology, geochemistry, and $\mathrm{Nd}$ isotopes of early Mesozoic bimodal volcanism in northern Tibet, western China: Constraints on the exhumation of the central Qiangtang metamorphic belt, Lithos, 121, 167175, 2011.

Zhang, Y., Shen, S., Shi, G., Wang, Y., and Yuan, D.: Tectonic evolution of the Qiangtang Block, northern Tibet during Late Cisuralian (Late Early Permian): Evidence from fusuline fossil records, Palaeogeogr. Palaeocl., 350, 139-148, 2012a.

Zhang, Y., Shi, G., and Shen, S.: A review of Permian stratigraphy, palaeobiogeography and palaeogeography of the Qinghai-Tibet Plateau, Gondwana Res., 24, 55-76, 2012 b.
Zhang, H., Yang, T., Hou, Z., Song, Y., Ding, Y., and Cheng, X.: Petrogenesis and tectonics of late Permian felsic volcanic rocks, eastern Qiangtang block, north-central Tibet: Sr and Nd isotopic evidence, Int. Geol. Rev., 1-12, 2013.

Zhang, Y., Shi, G., Shen, S., and Yuan, D.: Permian Fusuline Fauna from the Lower Part of the Lugu Formation in the Central Qiangtang Block and its Geological Implications, Acta Geol. Sin.Engl., 88, 365-379, 2014.

Zhao, G.: Jiangnan Orogen in South China: Developing from divergent double subduction, Gondwana Res., 27, 1173-1180, doi:10.1016/j.gr.2014.09.004, 2015.

Zhao, Z., Bons, P. D., Wang, G., Liu, Y., and Zheng, Y.: Origin and pre-Cenozoic evolution of the south Qiangtang basement, Central Tibet, Tectonophysics, 623, 52-66, 2014

Zhu, T.: Geological map of the Jiangaida Ri area (Scale at $1: 250000)$ : Geology and Resource Institute of Chengdu, China, 2005.

Zhu, D., Zhao, Z., Niu, Y., Dilek, Y., Hou, Z., and Mo, X.: The origin and pre-Cenozoic evolution of the Tibetan Plateau, Gondwana Res., 23, 1429-1454, 2012.

Zhu, T., Feng, X., Wang, X., and Zhou, M.: Reconstruction of the Triassic Tectonic Lithofacies Paleogeography in Qiangtang Region, Northern Qinghai, Tibet Plateau, China, Acta Geol. Sin.Engl., 87, 378-394, 2013. 